\title{
Soils of the Indo-Gangetic Plains: a pedogenic response to landscape stability, climatic variability and anthropogenic activity during the Holocene
}

\author{
Pankaj Srivastava $^{\text {a,* }}$, Dilip Kumar Pal ${ }^{\text {b }}$, K. Manini Aruche ${ }^{\text {a }}$, Suhas P. Wani ${ }^{\text {b }}$, Kanwar L. Sahrawat ${ }^{\text {b }}$ \\ a Department of Geology, University of Delhi, Delhi 110007, India \\ ${ }^{\mathrm{b}}$ Resilient Dry land Systems, International Crops Research Institute for the Semiarid Tropics (ICRISAT), Patancheru 502 324, Andhra Pradesh, India
}

\section{A R T I C L E I N F O}

\section{Article history:}

Received 31 January 2014

Accepted 31 October 2014

Available online 7 November 2014

\section{Keywords:}

Indo-Gangetic Plains (IGP)

Soil-geomorphology

Climate change

Neotectonics

Anthropogenic activity

Natural degradation

\begin{abstract}
A B S T R A C T
Bound by the Himalaya in the north and the Craton in the south, the Indo-Gangetic Plains (IGP) is one of the largest fluvial plains of the world. The IGP is monotonously flat with a spread of surface soils in hot arid conditions of Rajasthan in west to per-humid conditions in West Bengal. The soil-geomorphology of the IGP detailed during the last few decades is useful in determining the interrelationship among the pedogenesis, the climate, and the landscape evolution during the Holocene. These studies demonstrate that the IGP soils developed on five geomorphic surfaces with varying degree of development. Soils occurring on older geomorphic surfaces $(>2.5 \mathrm{ka})$ are polygenetic with a distinct record of climatic changes and neotectonics.

The present synthesis is based on recent developments in pedology achieved through macro- and micromorphology, clay mineralogy, pedogenic calcrete, and polygenetic pedogenic features of the IGP soils. A critical evaluation of the IGP soils has helped to comprehend the subtle nuances of the pedogenic processes that were also influenced by anthropogenic activities and cultivation over this vast agricultural tract during the Holocene. We provide state-of-the-art information on the pedology, polygenesis, and soil degradation (natural and anthropogenic) over the last $10 \mathrm{ka}$. The review has potential as a reference for critical assessment of the pedosphere for health and quality in different parts of the world. In addition, it facilitates developing a suitable management practices for the food security in the 21 st century.
\end{abstract}

(c) 2014 Elsevier B.V. All rights reserved.

\section{Contents}

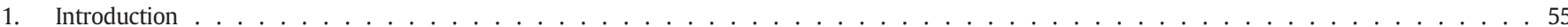

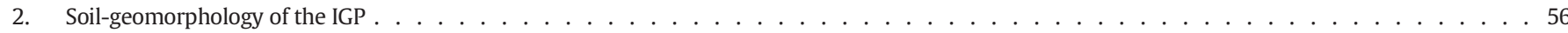

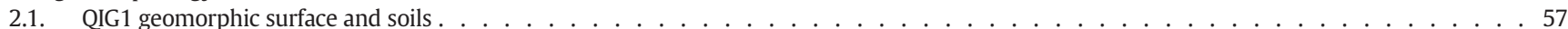

2.2. QIG2 geomorphic surface and soils . . . . . . . . . . . . . . . . . . . . . . . . . . . . . . 58

2.3. QIG3 geomorphic surface and soils . . . . . . . . . . . . . . . . . . . . . . . . . . . . . . . . . . . 58

2.4. QIG4 geomorphic surface and soils . . . . . . . . . . . . . . . . . . . . . . . . . . . . . . . 61

2.5. QIG5 geomorphic surface and soils . . . . . . . . . . . . . . . . . . . . . . . . . . . . . . . . . . 61

2.6. Significance of the geomorphic surfaces of the IGP . . . . . . . . . . . . . . . . . . . . . . . . . . . . . . . . . 61

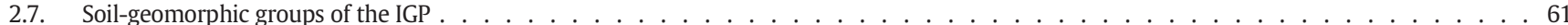

2.7.1. Ravi-Ghagghar Plains $(\mathrm{RGP}) \ldots \ldots \ldots \ldots \ldots$

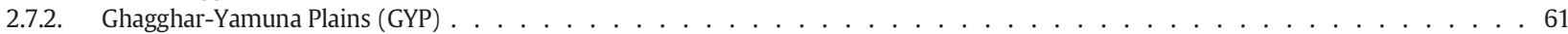

2.7.3. Yamuna-Ganga Interfluve $(\mathrm{YGI}) \ldots \ldots \ldots \ldots \ldots$

2.7.4. Ganga-Ghaghara Interfluve $(\mathrm{GGI}) \ldots \ldots \ldots \ldots$

2.7.5. Ghaghra-Rapti Plains $(G R P) \ldots \ldots \ldots \ldots$

2.7.6. Gandak Megafan $(\mathrm{GMF}) \ldots \ldots \ldots \ldots$

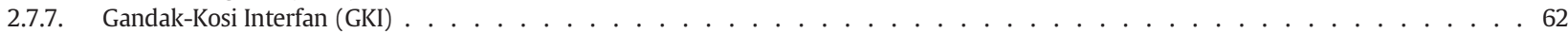

2.7.8. Kosi Megafan $(\mathrm{KMF}) \ldots \ldots \ldots \ldots \ldots$

2.7.9. Mahananda-Tista Plains (MTP) . . . . . . . . . . . . . . . . . . . . . . . . . . . . . . 62

2.7.10. Barind Tract $(\mathrm{BT}) \ldots \ldots \ldots \ldots \ldots$

\footnotetext{
* Corresponding author.

E-mail address: pankajps@gmail.com (P. Srivastava).
} 


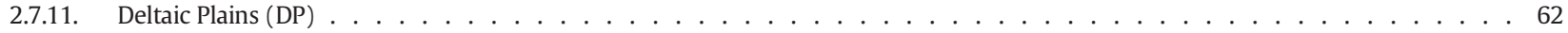

2.7.12. Tista-Brahmaputra Plains $(\mathrm{TBP}) \ldots \ldots \ldots \ldots$

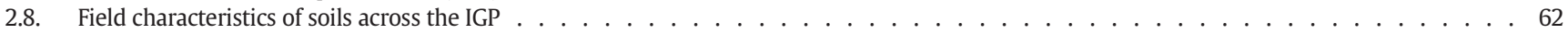

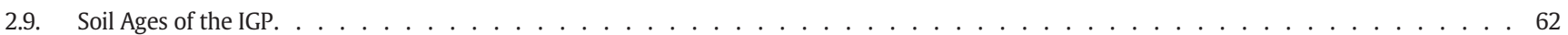

3. Holocene climatic fluctuations and pedogenic response of IGP soils . . . . . . . . . . . . . . . . . . . . . . . . . . . . 62

4. Neotectonics and pedogenic response of IGP soils ． . . . . . . . . . . . . . . . . . . . . . . . . . . . . . . 63

5. Soils of the IGP: climatic variability, pedogenic processes, and taxonomic classes . . . . . . . . . . . . . . . . . . . . . 64

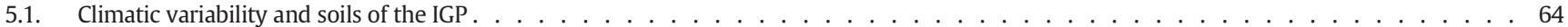

5.2. Pedogenic processes and taxonomic classes of soils in IGP . . . . . . . . . . . . . . . . . . . . . . . 65

5.3. Mineralogical Class of soils in IGP . . . . . . . . . . . . . . . . . . . . . . . . . . . . . 68

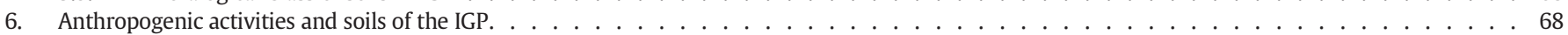

6.1. Origin and dispersal of agriculture and its impact on soils of IGP . . . . . . . . . . . . . . . . . . 68

6.2. Natural and anthropogenic degradations and management intervention in IGP soils . . . . . . . . . . . . . . . . . . . . . . . . . 69

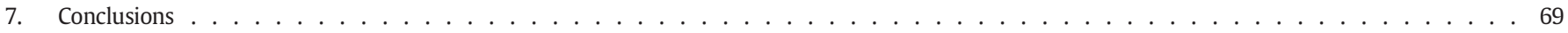

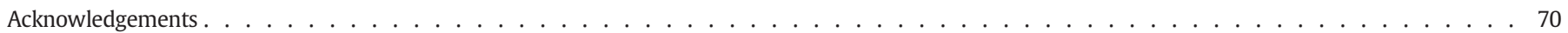

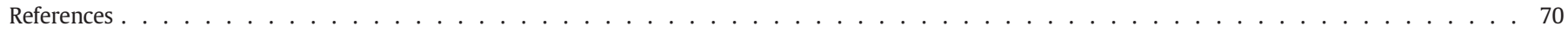

\section{Introduction}

The Indo-Gangetic Plains (IGP) is a "foredeep" depression between the Indian Peninsula to the south and the Himalaya in the north (Wadia, 1966). Geological studies, geophysical surveys and deep drillings by the Oil and Natural Gas Commission of India reveal that the IGP is a vast asymmetric trough with maximum thickness of about $10 \mathrm{~km}$ in the foothills to the north and a minimum of few meters in the south towards craton (Wadia, 1966; Sastri et al., 1971; Rao, 1973; Raiverman et al., 1983; Parkash and Kumar, 1991). Origin of the foredeep is linked to the Himalayan orogeny caused by the collision of Indian and Tibetan plates at ca $50 \mathrm{Ma}$ (Klootwijk et al., 1992; Gaina et al., 2007; Kumar et al., 2007; Kent and Muttoni, 2008). The Indian Plate is still moving at the rate of $2-5 \mathrm{~cm} / \mathrm{y}$ towards the north and the compression generated throughout the plate ensures that it is continuously under stress providing the basic source of strain in the fractured zones (Gaur, 1994).

The fluvial deposits and landforms of the IGP have been influenced by the neotectonics during the Holocene. The major rivers of the IGP have changed their courses and, at present, are flowing towards southeast and easterly directions with convexity towards the southwest under the influence of major thrusts bordering the IGP (Parkash et al., 2000). The IGP is mainly drained by Himalayan Rivers such as the Indus, the Yamuna, the Ganga, the Ramganga, the Ghaghara, the Rapti, the Gandak, the Bhagirathi, the Silai, the Damodar, the Ajay, the Kosi, and the Brahmaputra rivers and also by the rivers originating in the Craton from the south such as the Chambal, the Betwa, and the Son rivers (Fig. 1). The overall topography of the IGP is remarkably flat with a gradient of $<0.02 \%$ from the Punjab ( $300 \mathrm{~m} \mathrm{msl}$ ) in the west to the eastern delta of West Bengal (1.5$9.0 \mathrm{~m} \mathrm{msl}$ ) (Fig. 2).

The IGP is one of the most extensive fluvial plains of the world with an aerial extent of about $5.0 \times 10^{5} \mathrm{~km}^{2}$. It accounts for the one third cultivable lands and a major contributor of the food supply for the Indian population. The evidence from many archaeological sites of the IGP show considerable changes from incipient agricultural activities to well developed agricultural practices in the IGP during the last 10,000 years (Sharma et al., 1980; Kumar et al., 1996; Misra, 2001; Fuller, 2006; Saxena et al., 2006; Williams et al., 2006). Agriculture was the mainstay of the people of ancient India and the agriculturists were aware of variations in productivity of different types of soils (Raychaudhuri, 1975; Velayutham and Pal, 2004). Archaeological lines of evidence further indicate that western parts of the IGP were the ancient agricultural centres ( $10 \mathrm{ka})$ from where dispersal of domestication and anthropogenic activities took place towards the eastern and the southern parts of India (Fuller, 2006; Chen et al., 2010).
The surface soil remains the firm foundation of human life thriving on it. However, modern use and abuse of soils has made it one of the most degraded and least understood ecosystems in terms of its relationship with people. The knowledge of the IGP soils is important for understanding the long-term human interactions (Williams and Clarke, 1984, 1995; Williams et al., 2006; Gibling et al., 2008). The ancient literature of India ('Vishnu Purana' from the first century C.E.) suggests that the early farmers had the knowledge of soils, landforms, erosion, flooding, sedimentation, vegetation, land use, water and human health (McNeill and Winiwarter, 2004; Wasson, 2006). Scientific characterization of the the IGP soils can be traced back to the first half of 19th century when the Geological Survey of India started studying the soils and the underlying strata in 1846 (Raychaudhuri, 1975; Velayutham et al., 2002). The IGP soils were defined as one of the four major soils groups in India (Voelcker, 1893; Leather, 1898). Wadia et al. (1935) note that soil group boundaries were nearly co-incident with the major lithotectonic boundaries. During the past five decades various soil-forming processes such as calcification, leaching, lessivage, salinization and alkalinization, gleization and homogenization have been identified in the IGP (Shankarnarayana and Sarma, 1982). These processes lead to the formation of a variety of soils in the IGP that represent mainly three soil orders - Entisols, Inceptisols and Alfisols (Shankarnarayana and Sarma, 1982). Recent studies, however, indicate that Mollisols, Aridisols, and Vertisols are also present in the IGP (Bhattacharyya et al., 2004; Ray et al., 2006).

The intimate relationship of soils and landforms forms the sound basis for the use of soils in geological studies (Ruhe, 1956, 1960, 1964; Richmond, 1962; Morrisson, 1964, 1965). The critical factors that influence soil-formation are climate, biotic activity, relief, parent material, and the age of the geomorphic surface (Jenny, 1941). The application of soils in geomorphic research is now a wellestablished approach as "soil-geomorphology" for understanding the genetic relationships between the soils and the landscape elements (Birkeland, 1990; McFadden and Knuepfer, 1990). It is due to the fact that soils form an essential component of any landscape and the history of any landscape evolution is intimately tied with the history of soil development (Birkeland, 1990). The application of a soil geomorphic approach to soil landscape studies has led to a more quantitative evaluation of the geomorphic processes operating over different time scales ranging from $10^{3}$ to $10^{5}$ years (Ritter, 1986). Soil-geomorphic studies over the last three decades have demonstrated that soil development "functions" help in determining the interrelationship among time, climate, landscape development and the soil-forming processes (Birkeland, 1990; Harden, 1990; McFadden and Knuepfer, 1990).

The soil-chronosequences are potentially useful to estimate rates of soil development and landscape evolution over different time 


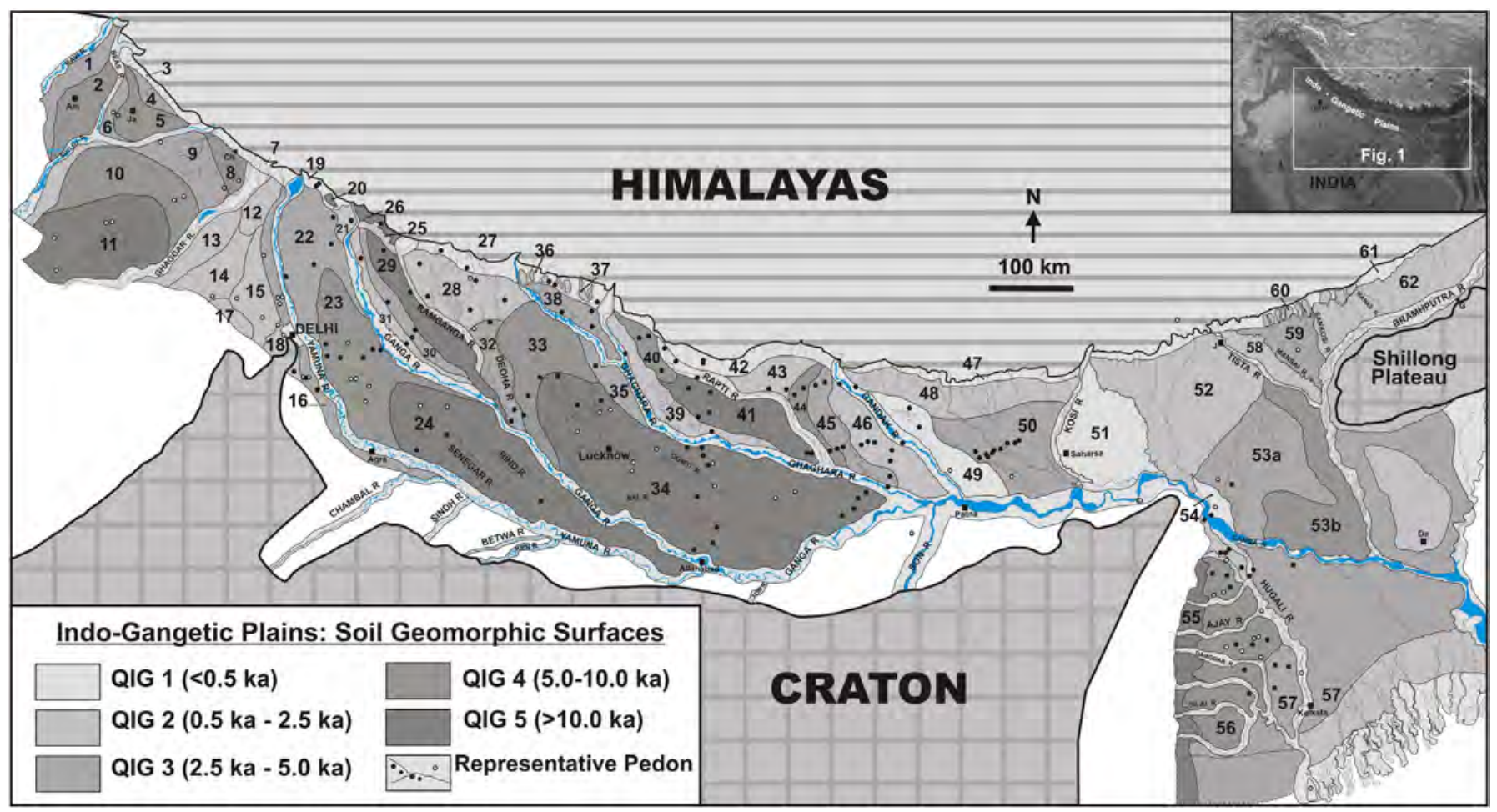

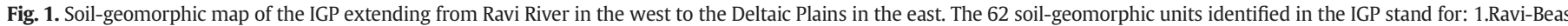

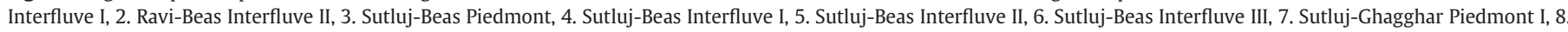

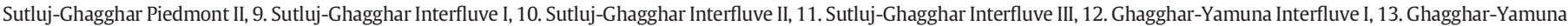

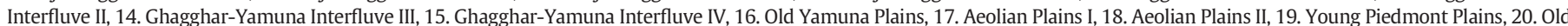

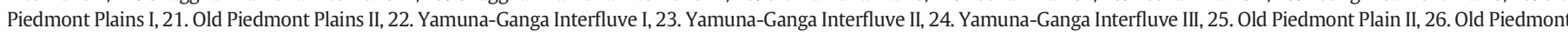

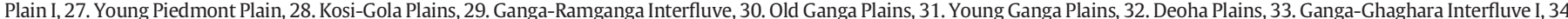

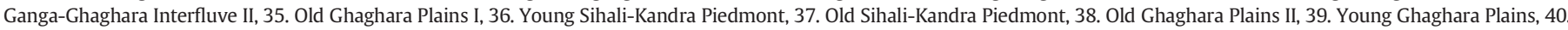

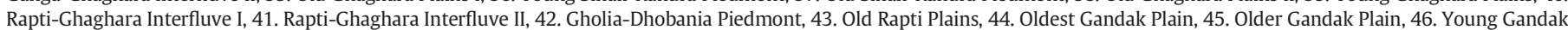

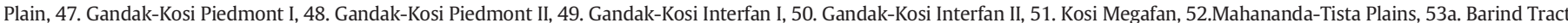

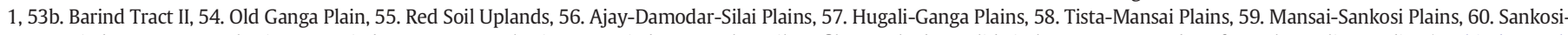

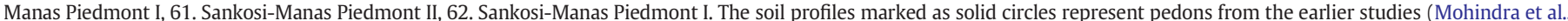

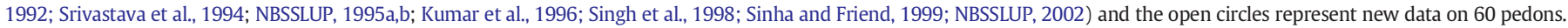

scales (Harden, 1990; Huggett, 1998). Amongst the four types of soilchronosequences, the post-incisive soil chronosequences are the most commonly studied chronosequences that result in a sequence of progressively younger surfaces in which soils formation may begin (Vreeken, 1975; Huggett, 1998). For a systematic soil-geomorphic investigation dealing with soil genesis and landscape evolution the procedures by Birkeland $(1974,1999)$ provides the critical framework and staple reference. In India, the soil-geomorphic approach using pedological and geomorphic methods was applied to decipher the soil geomorphic history of different parts of the IGP (Singhai et al., 1991; Mohindra et al., 1992; Srivastava et al., 1994; Kumar et al., 1996; Singh et al., 1998; Khan et al., 2005).

A comprehensive synthesis of the subtle nuances of pedogenic processes in response to climate change, neotectonics and anthropogenic activities in the entire IGP is, however, lacking. As the IGP is also drained by rivers of the Indian Craton to the south, the role of cratonic flux (sediments from gneissic and basaltic rocks as source) in genesis of the IGP soils with vertic characters requires an adequate attention (Tandon et al., 2008; Pal et al., 2012a). There is an obvious need for critical assessment of the soils in the IGP for understanding the pedogenic response to climate change and neotectonics during the Holocene time. The synthesis of the IGP soils is significant because of the unique position of the Indian subcontinent and the rising Himalayas that influence monsoon, landscapes and vegetation at both regional and global scales. In addition to the existing information, new data from 60 pedons spread from west to east of the IGP, are also included in the synthesis presented in this article. The assessment of the IGP soils establishes the contemporary pedogenic processes as well as polygenetic pedogenic history from different geomorphic surfaces.

\section{Soil-geomorphology of the IGP}

The research on soil-geomorphology in India was initiated in the 1980 's by a group of researchers from the University of Roorkee now known as Indian Institute of Technology Roorkee. Their investigations covered almost $40 \%$ of the IGP and laid down the foundation of soil geomorphic studies in India (Singhai et al., 1991; Mohindra et al., 1992; Srivastava et al., 1994; Kumar et al., 1996; Singh et al., 1998; Khan et al., 2005). An integrated approach using pedological and geomorphic methods was applied to decipher Holocene soil-geomorphic history in different parts of the IGP. It is now established that the vast and flat Gangetic Plains are characterized by more than two geomorphic surfaces and the Holocene climate changes are recorded in polygenetic soils (Srivastava et al., 1994; Srivastava and Parkash, 2002).

In this article, we give comprehensive information on soilgeomorphic features in the entire IGP extending from the Ravi River in the west to deltaic plains in the east (Fig. 1). The soilgeomorphology of the IGP is described in terms of soil-geomorphic units, degree of soil development, geomorphic surfaces, and soilgeomorphic groups. Based on synthesis of published soil-geomorphic work and new data from 60 pedons, we have identified 62 soil geomorphic units and 12 soil-geomorphic groups in the entire IGP. Degree of development and duration of pedogenesis in each soil-geomorphic unit suggests origin and stabilisation of five geomorphic surfaces over 

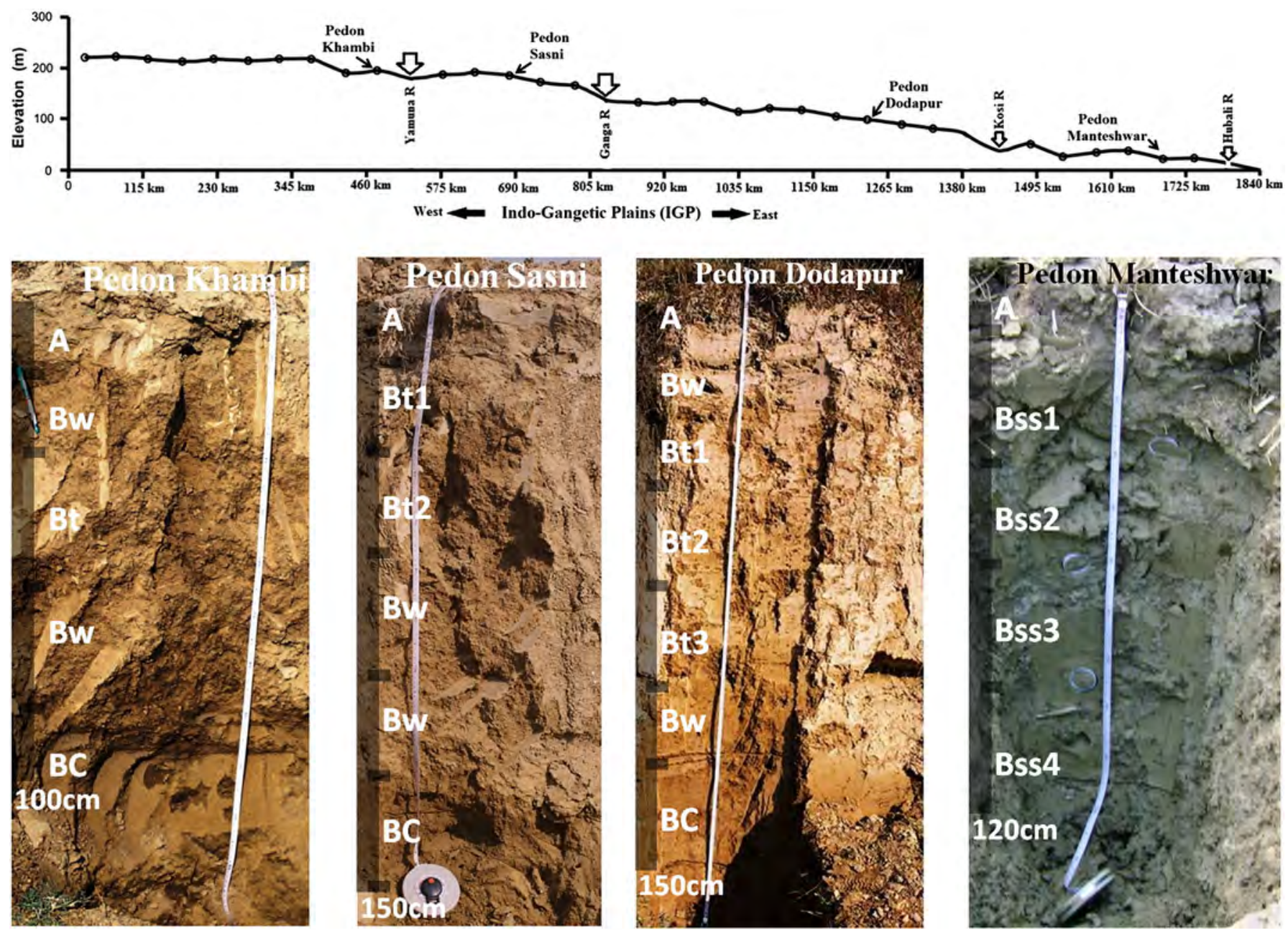

Fig. 2. Topographic profile extending from west to east of the IGP with locations of major rivers and pedons. Field photographs of the 4 representative pedons showing varying colour, texture, Bw/Bt/Bss, and thickness of the soil profiles across the IGP from west to east. Pedon Khambi (191 m msl, SAD climate, silty loam, $25 \mathrm{~cm}$ thick Bt horizon, 10-15\% PC, QIG3 surface); Pedon Sasni (184 m msl, SAD climate, sandy loam, $50 \mathrm{~cm}$ thick Bt horizon, 5-10\% PC, QIG4 surface); Pedon Dodapur (102 m msl, SAD-SHM climate, silty clay loam, >100 cm thick Bt horizon, QIG5 surface); Pedon Manteshwar (11 m msl, SHM climate, silty clay loam, 60-80 cm thick Bss horizon, QIG4 surface).

the last $13.5 \mathrm{ka}$ in the IGP. These are spread over different landforms like floodplains, piedmonts, alluvial plains, old river plains, and interfluves.

A soil-geomorphic unit is defined by distinctive features on IRS images on account of varying characteristics of surface soils and sediments (Mohindra et al., 1992; Srivastava et al., 1994). For example a darker tone and uniform red colour is noticed in soil-geomorphic units having sediment accumulation and ample moisture, e. g. floodplains and piedmonts (units 36 and 39 of Ghaghara-Rapti Plains; Fig. 1). The soilgeomorphic units that are not affected by sediment accumulation are generally brighter and light red with mottling, e.g. interfluves (units 22-24 of Yamuna-Ganga Interfluve; Fig. 1). Field evidence and lab work confirmed differences in soils characteristics of these soilgeomorphic units. An integrated approach based on the thickness of B horizon, the clay accumulation index (Levine and Ciolkosz, 1983), the degree of pedality (Bullock et al., 1985), and the thickness and the nature of clay pedofeatures and pedogenic carbonates was applied to evaluate the degree of development in different soil-geomorphic units (Mohindra et al., 1992; Srivastava et al., 1994).

The characterization of a geomorphic surface is based on degree of development and duration of pedogenesis (Mohindra et al., 1992; Srivastava et al., 1994; Singh et al., 1998). Pedogenic studies of the IGP confirm that origin and stabilisation of different geomorphic surfaces occurred during slight uplift of a region above the general level of rivers that led to the termination of sedimentation and initiation of pedogenic activity (Srivastava et al., 1994; Kumar et al., 1996; Singh et al., 1998).
This led to the formation of the least developed soils close to channels, alluvial fans, and piedmonts where sediment accumulation rates are high, whereas the most developed soils formed in upland interfluves and old river plains, where sediment accumulation rates are significantly less (Srivastava et al., 1994; Kumar et al., 1996; Singh et al., 1998). Accordingly, mature/well-developed soils showing strongly to very strongly developed pedofeatures formed on old geomorphic surfaces originating at $8000-13500$ years B.P. (Table 1 and Table 2 ). By contrast, the immature or poorly developed soils with little or no pedogenesis formed on young geomorphic surfaces over the last 500 years of age (Tables 1 and 2). The degree of soil development in each of the 62 units has been critically evaluated and compared with available soilgeomorphic data of the IGP for determining the type of geomorphic surfaces (Table 1). Following these criteria at least five geomorphic surfaces, namely QIG1 to QIG5 with ages of $<0.5 \mathrm{ka}, 0.5-2.5 \mathrm{ka}, 2.5-$ $5.0 \mathrm{ka}, 5-10 \mathrm{ka}$, and $>10 \mathrm{ka}$, are delineable on the 62 soil-geomorphic units (Tables 1 to 3). Each of the five geomorphic surfaces is characterized by a distinctive pedogenic record. Typical pedogenic features of the five geomorphic surfaces of the IGP are listed below.

\subsection{QIG1 geomorphic surface and soils}

This geomorphic surface is characterized by poorly developed soils on young piedmonts, alluvial fans, and floodplains (e.g. units 3, 7, 19, 27, 36, 42, 47, 49, 51, 60; Fig. 1; Table 3). Soils over this geomorphic 
Table 1

Criteria for determining relative maturity of the soils and geomorphic surfaces of the IGP (after Srivastava et al., 1994; Kumar et al., 1996; Singh et al., 1998).

\begin{tabular}{|c|c|c|c|}
\hline \multirow[t]{2}{*}{$\begin{array}{l}\text { Geomorphic surface, } \\
\text { Age (ka) }\end{array}$} & \multirow[t]{2}{*}{ Representative soil-geomorphic units } & $\begin{array}{l}\text { Typical features of a Pedon (after Srivastava } \\
\text { et al., 1994) }\end{array}$ & \multirow[t]{2}{*}{ Degree of soil development } \\
\hline & & $\begin{array}{l}\text { Horizonation, B horizon thickness, Structure, } \\
\text { Texture, Pedogenic carbonate (PC), } \\
\text { Classification }\end{array}$ & \\
\hline QIG1 (<0.5 ka) & $\begin{array}{l}\text { Units 36, } 42 \text { in floodplains and piedmonts } \\
\text { (Fig. 1) }\end{array}$ & $\begin{array}{l}\text { Ap/C, 0-15 cm, Massive, Sandy loam, 2-4\% PC } \\
\text { in lower horizons, Typic Ustorthent }\end{array}$ & $\begin{array}{l}\text { Little or no pedogenesis in youngest } \\
\text { geomorphic surface }\end{array}$ \\
\hline QIG2 (0.5-2.5 ka) & $\begin{array}{l}\text { Units } 28,37,39 \text { in young river plains and } \\
\text { remnant piedmonts (Fig. 1) }\end{array}$ & $\begin{array}{l}\mathrm{Ap} / \mathrm{Bw} / / \mathrm{BC}, 20-50 \mathrm{~cm} \text {, Weak subangular } \\
\text { blocky, Sandy and silty loam, 2-5\% PC in Bw } \\
\text { horizons, Typic Ustochrept }\end{array}$ & $\begin{array}{l}\text { Weakly developed soils with thin } 20-30 \mu \mathrm{m} \\
\text { thick clay pedofeatures }\end{array}$ \\
\hline QIG3 (2.5-5 ka) & $\begin{array}{l}\text { Units } 22,32,35 \text { in old river plains and upper } \\
\text { interfluves (Fig. 1) }\end{array}$ & $\begin{array}{l}\text { Ap/Bw/Bt/BC, } 50-85 \mathrm{~cm} \text {, Moderate } \\
\text { subangular blocky, Silty loam, } 2-10 \% \text { PC in } \\
\text { Bw/Bt horizons, Typic Ustochrept and Typic } \\
\text { Haplustalfs }\end{array}$ & $\begin{array}{l}\text { Moderately developed soils with } 50-60 \mu \mathrm{m} \\
\text { thick clay pedofeatures }\end{array}$ \\
\hline QIG4 (5-8 ka) & $\begin{array}{l}\text { Units } 10,23,33,40 \text { in middle parts of } \\
\text { interfluves (Fig. 1) }\end{array}$ & $\begin{array}{l}\text { Ap/Bw/Bt/BC, } 80-100 \mathrm{~cm} \text {, Strong subangular } \\
\text { blocky, Silty clay loam, little or no PC, Typic } \\
\text { Haplustalfs }\end{array}$ & $\begin{array}{l}\text { Strongly developed soils with } 80-100 \mu \mathrm{m} \\
\text { thick clay pedofeatures }\end{array}$ \\
\hline QIG5 (>10 ka) & $\begin{array}{l}\text { Interfluves Units } 5,8,11,20,24,34 \text { in lower } \\
\text { parts of interfluves and oldest piedmonts } \\
\text { (Fig. 1) }\end{array}$ & $\begin{array}{l}\text { Ap/Bw/Bt/BC, } 100-130 \mathrm{~cm} \text {, Very strong } \\
\text { subangular blocky, Silty clay loam, 2-5\% PC in } \\
\text { Bt horizons, Typic Haplustalfs }\end{array}$ & $\begin{array}{l}\text { Very strongly developed soils with } 100- \\
200 \mu \mathrm{m} \text { thick clay pedofeatures }\end{array}$ \\
\hline
\end{tabular}

surface are usually characterized by A/C profiles rarely with thin (15$20 \mathrm{~cm}$ ) Bw horizons. Micromorphology of the soils from this geomorphic surface showed apedal to weakly developed subangular blocky structure, fresh to weakly altered mineral grains, lithorelicts, and undifferentiated b-fabrics (Srivastava and Parkash, 2002). Pedogenic carbonate as micritic nodules is common only in piedmont soils of the west, but a rare feature in floodplain soils. Tentative age of this geomorphic surface is assigned as $<0.5 \mathrm{ka}$ on account of little or no pedogenesis (Mohindra et al., 1992; Srivastava et al., 1994).

\subsection{QIG2 geomorphic surface and soils}

It is defined by weakly developed soils on remnant piedmonts, river plains, and alluvial fans that were stabilised during $0.5 \mathrm{ka}$ to $2.5 \mathrm{ka}$ (e. g. units $12-15,17,18,20,25,28,31,37,39,46,48,52$, 54, 58, 61, 62; Fig. 1; Table 3). Soils over this geomorphic surface are characterized by $25-$
$45 \mathrm{~cm}$ thick Bw horizons that show weak-moderate pedality and subangular blocky structures (Mohindra et al., 1992; Srivastava et al., 1994; Kumar et al., 1996; Singh et al., 1998). Thin (20-30 $\mu \mathrm{m})$ illuvial clay pedofeatures are common but $<1 \%$ in the Bw horizon of these soils. Coarse mineral grains show weak alteration defined by bleaching and exfoliation of biotite and formation of clay minerals after feldspars. It is characterized by weak to moderate cross striated b-fabrics. Pedogenic carbonate as diffused nodules of micrite is common feature with extensive dissolution and reprecipitation features in soils over western and central parts of the IGP (Mohindra et al., 1992; Srivastava et al., 1994; Kumar et al., 1996).

\subsection{QIG3 geomorphic surface and soils}

This geomorphic surface is defined by moderately-to-strongly developed soils in old river plains and upper parts of interfluves that

Table 2

Soil ages based on C14, TL, Archaeological, and Historical evidences.

\begin{tabular}{|c|c|c|c|}
\hline $\begin{array}{l}\text { Soil Geomorphic unit } \\
\text { (Fig. 1) }\end{array}$ & Geomorphic surface & C14, TL/OSL, Archaeological, Historical evidence & Reference \\
\hline 11 & QIG 5 & $\begin{array}{l}\text { C14 age data: Sambhar Lake, Rajasthan }(3.2 \mathrm{~m}: 9250 \pm 130 \mathrm{yrs} \\
2.8 \mathrm{m:}: 8300 \pm 135 \mathrm{yrs} ; 1.9 \mathrm{~m}: 6235 \pm 315 \mathrm{yrs} ; 1.4 \mathrm{~m}: \\
4510 \pm 135 \mathrm{yrs})\end{array}$ & Singh et al. (1974) \\
\hline 15 & QIG 2 & $\begin{array}{l}\text { C14 age data: Rewasa, Bhiwani, Holocene lake, Haryana (1.2 m: } \\
3640 \pm 90 \text { yrs) }\end{array}$ & Bhatia and Singh (1988) \\
\hline $12-15$ & QIG 2 & $\begin{array}{l}\text { Archaeological evidence and shifting of paleochannels } \\
\text { - Early Harrapan (2500-1700BC): wet climate; Sutluj and } \\
\text { Yamuna tributaries to Ghagghar } \\
\text { - Late Harrapan (1700-1000 BC): Dry climate; Sutluj and Yamuna } \\
\text { tributaries to Ghagghar shifted towards present course }\end{array}$ & $\begin{array}{l}\text { Pal et al. (1980); Singh (1971); Singh et al. } \\
\text { (1974) }\end{array}$ \\
\hline 23 & QIG 4 & $\begin{array}{l}\text { - C14 age of calcrete (6500 BP) } \\
\text { - TL date ( } 8300 \mathrm{BP})\end{array}$ & $\begin{array}{l}\text { Kumar et al. (1996); Das (1993); Srivastava } \\
\text { et al. (1994) }\end{array}$ \\
\hline 22 & QIG 3 & $\begin{array}{l}\text { - Hub of Ochre Pottery Culture (1900 BC-1000 BC) } \\
\text { - TL dates of } 4 \text { unpaired terraces (T0-T3) above Solani River (T3 } \\
\text { and T2: } 2500 \mathrm{BP} \text { and } 1600 \mathrm{BP} \text { ) }\end{array}$ & $\begin{array}{l}\text { Misra (1984), Kumar et al. (1996); Vohra } \\
\text { (1987) }\end{array}$ \\
\hline 34 & QIG 5 & $\begin{array}{l}\text { - C14 age of calcretes ( } 11000 \mathrm{BP}-9000 \mathrm{BP}) \\
\text { - TL date }(13600 \mathrm{BP})\end{array}$ & $\begin{array}{l}\text { Rajagopalan (1992); Das (1993); Srivastava } \\
\text { et al. (1994) }\end{array}$ \\
\hline $44-46$ & QIG 2-QIG4 & $\begin{array}{l}\text { Historical evidence of eastward shift of Gandak river ( } 80 \mathrm{~km} \text { over } \\
\text { the last } 5000 \mathrm{yrs} \text { ) }\end{array}$ & Mathur (1969); Mohindra et al. (1992) \\
\hline $49-50$ & QIG 1-QIG3 & $\begin{array}{l}\text { C14 ages ( } 2.0 \mathrm{m:}: 2400 \pm 45 \text { yrs BP, } 1.5 \mathrm{~m}: 1100 \pm 45 \text { yrs BP, } \\
0.5 \mathrm{~m}: 765 \pm 45 \text { yrs BP) }\end{array}$ & Sinha et al. (1996) \\
\hline 54 & QIG 2 & TL age $(1.5 \mathrm{ka})$ & Singh et al. (1998) \\
\hline 57 & QIG 3 & TL age (3.5 ka) & Singh et al. (1998) \\
\hline 56 & QIG 4 & TL age (5.4-6.5 ka) & Singh et al. (1998) \\
\hline 55 & QIG 5 & Early-Middle Pleistocene (Lateritic uplands) & Singh et al. (1998) \\
\hline
\end{tabular}


Table 3

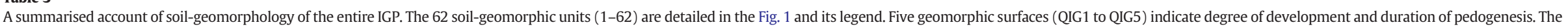
12 soil-geomorphic groups of the IGP contain various soil-geomorphic units and geomorphic surfaces and are defined in Section 2.7 of the article. The climatic zones (HA to PH) are detailed in legend of the Fig. 5.

\begin{tabular}{|c|c|c|c|c|c|c|c|}
\hline \multirow[t]{2}{*}{$\begin{array}{l}\text { Soil Geo- morphic } \\
\text { unit no }\end{array}$} & \multirow[t]{2}{*}{ Climate (MAR mm) } & $\begin{array}{l}\text { Degree of soil } \\
\text { development }\end{array}$ & Geo morphic surface & Soil Age & \multirow[t]{2}{*}{ Dominant Soil Order } & \multirow[t]{2}{*}{$\begin{array}{l}\text { Reference ( } 125 \text { pedons marked as dark } \\
\text { circles in Fig. } 1 \text {; after referred works) }\end{array}$} & \multirow[t]{2}{*}{$\begin{array}{l}\text { New data ( } 60 \text { pedons marked as open circles in } \\
\text { Fig. 1; after Pal et al., 2010; Aruche, 2014) }\end{array}$} \\
\hline & & \multicolumn{3}{|c|}{$\begin{array}{l}\text { Estimate after Srivastava et al., 1994; Kumar et al., 1996; } \\
\text { Singh et al., } 1998\end{array}$} & & & \\
\hline \multicolumn{8}{|c|}{ Ravi-Ghagghar Plains (RGP) } \\
\hline 1 & HA-SAD (450) & Moderate & QIG 3 & $2.5-5 \mathrm{ka}$ & Inceptisols, Alfisols & Sehgal, 1974; NBSSLUP 1995a & - \\
\hline 2 & HA-SAD (450) & Strong & QIG 4 & $5-10 \mathrm{ka}$ & Alfisols & -do- & - \\
\hline 3 & SAD (675) & Very weak & QIG 1 & $<0.5 \mathrm{ka}$ & Entisols & -do & - \\
\hline 4 & SAD (675) & Strong & QIG 4 & $5-10 \mathrm{ka}$ & Alfisols & -do- & - \\
\hline 5 & SAD (500) & Very strong & QIG 5 & $>10 \mathrm{ka}$ & Vertic Haplustalfs & -do- & Dhadde, Jagitpur \\
\hline 6 & HA-SAD (400) & Strong & QIG 4 & $5-10 \mathrm{ka}$ & Alfisols & -do- & - \\
\hline 7 & SAM-SHD (875) & Very weak & QIG 1 & $<0.5 \mathrm{ka}$ & Entisols & -do- & - \\
\hline 8 & SAM-SHD (905) & Very strong & QIG 5 & $>10 \mathrm{ka}$ & Oxyaquic Haplustalfs & -do- & Berpura \\
\hline 9 & SAD (674) & Moderate & QIG 3 & $2.5-5 \mathrm{ka}$ & $\begin{array}{l}\text { Typic Ustipsamments, } \\
\text { Inceptic Haplustalfs }\end{array}$ & -do- & Bhanra, Fatehpur \\
\hline 10 & SAD (674) & Strong & QIG 4 & $5-10 \mathrm{ka}$ & Oxyaquic Haplustalfs & -do- & Phaguwala \\
\hline 11 & $\mathrm{HA}(265)$ & Very strong & QIG 5 & $>10 \mathrm{ka}$ & $\begin{array}{l}\text { Torrifluventic Haplustalfs, } \\
\text { Aridic Haplustalfs }\end{array}$ & -do- & Masitwali, Nihalkhera, Jodhpur Ramana \\
\hline \multicolumn{8}{|c|}{ Ghagghar-Yamuna Plains (GYS) } \\
\hline 12 & SAM-SHD (875) & Weak & QIG 2 & $0.5-2.5 \mathrm{ka}$ & Inceptisols & Singhai et al., 1991; NBSSLUP 1995b & - \\
\hline 13 & SAD (625) & Weak & QIG 2 & $0.5-2.5 \mathrm{ka}$ & Inceptisols & -do- & - \\
\hline 14 & SAD (625) & Weak & QIG 2 & $0.5-2.5 \mathrm{ka}$ & Inceptisols & - & Maham \\
\hline 15 & SAD (625) & Weak & QIG 2 & $0.5-2.5 \mathrm{ka}$ & Inceptisols & - & Nonand, Bahadurgarh \\
\hline 16 & SAD 720 & Moderate & QIG 3 & $2.5-5 \mathrm{ka}$ & Typic Natrustalfs, Inceptisols & Singhai et al., 1991; NBSSLUP 1995b; & $\begin{array}{l}\text { Zarifa Viran, Khambi, Bamnikhera, Singhu, } \\
\text { Jatikalan, Alipur }\end{array}$ \\
\hline 17 & HA (400) & Weak, & QIG 2 & $0.5-2.5 \mathrm{ka}$ & Inceptisols & Singhai et al., 1991; NBSSLUP 1995b & - \\
\hline 18 & $\operatorname{SAD}(550)$ & Weak, & QIG 2 & $0.5-2.5 \mathrm{ka}$ & Inceptisols & Singhai et al., 1991; Kumar et al., 1996 & IGI, Shanticolony \\
\hline \multicolumn{8}{|c|}{ Yamuna-Ganga Interfluve (YGI) } \\
\hline 19 & SHM, (1250) & Very weak & QIG 1 & $<0.5 \mathrm{ka}$ & Entisols & Kumar et al., 1996 & - \\
\hline 20 & SHM, (1250) & Very Strong & QIG 5 & $>10 \mathrm{ka}$ & Alfisols & -do- & - \\
\hline 21 & SHM, (1250) & Weak & QIG 2 & $0.5-2.5 \mathrm{ka}$ & Inceptisols & -do- & - \\
\hline 22 & SAD (675) & Moderate, & QIG 3 & $2.5-5 \mathrm{ka}$ & Inceptisols, Alfisols & -do- & - \\
\hline 23 & SAD (650) & Strong & QIG 4 & $5-10 \mathrm{ka}$ & Alfisols & -do- & Hirapur, Sakit, Jattari, Lodha, Sasni \\
\hline 24 & SAD-SHM (875) & Very strong & QIG 5 & $>10 \mathrm{ka}$ & Alfisols & -do- & Pawasgaon, Hanumanta \\
\hline \multicolumn{8}{|c|}{ Ganga-Ghaghara Interfluve (GGI) } \\
\hline 25 & SAD-SHM $(875$ & Weak & QIG 2 & $0.5-2.5 \mathrm{ka}$ & Inceptisols & Kumar et al., 1996 & - \\
\hline 26 & SHM (1252) & Very strong & QIG 5 & $>10 \mathrm{ka}$ & Typic Haplustalfs & -do- & Haldi \\
\hline 27 & SHM (1250) & Very weak & QIG 1 & $<0.5 \mathrm{ka}$ & Entisols & Srivastava et al., 1994 & - \\
\hline 28 & SAD-SHM (875) & Weak & QIG 2 & $0.5-2.5 \mathrm{ka}$ & Inceptisols & -do- & - \\
\hline
\end{tabular}




\begin{tabular}{|c|c|c|c|c|c|c|c|}
\hline \multirow[t]{2}{*}{$\begin{array}{l}\text { Soil Geo- morphic } \\
\text { unit no }\end{array}$} & \multirow[t]{2}{*}{ Climate (MAR mm) } & $\begin{array}{l}\text { Degree of soil } \\
\text { development }\end{array}$ & Geo morphic surface & Soil Age & \multirow[t]{2}{*}{ Dominant Soil Order } & \multirow[t]{2}{*}{$\begin{array}{l}\text { Reference ( } 125 \text { pedons marked as dark } \\
\text { circles in Fig. 1; after referred works) }\end{array}$} & \multirow[t]{2}{*}{$\begin{array}{l}\text { New data (60 pedons marked as open circles in } \\
\text { Fig. 1; after Pal et al., 2010; Aruche, 2014) }\end{array}$} \\
\hline & & \multicolumn{3}{|c|}{$\begin{array}{l}\text { Estimate after Srivastava et al., 1994; Kumar et al., 1996; } \\
\text { Singh et al., } 1998\end{array}$} & & & \\
\hline 29 & SAD-SHM (875) & Very strong & QIG 5 & $>10 \mathrm{ka}$ & Alfisols & Kumar et al., 1996 & - \\
\hline 30 & SAD-SHM (875) & Moderate, & QIG 3 & $2.5-5 \mathrm{ka}$ & Inceptisols, Alfisols & -do- & - \\
\hline 31 & SAD-SHM (875) & Weak & QIG 2 & $0.5-2.5 \mathrm{ka}$ & Inceptisols & -do- & - \\
\hline 32 & SAM-SHD (1052) & Moderate, & QIG 3 & $2.5-5 \mathrm{ka}$ & Typic Haplustalfs & Srivastava et al., 1994 & Simiri \\
\hline 33 & SAD-SHM (875) & Strong & QIG 4 & $5-10 \mathrm{ka}$ & Alfisols & -do- & - \\
\hline 34 & SAD-SHM (875) & Very strong & QIG 5 & $>10 \mathrm{ka}$ & Alfisols & -do- & $\begin{array}{l}\text { Hakimkheda, Naryanpur, Gangaganj, Bhajakheda, } \\
\text { Gaurwa, Bikapur, Dodapur, Bhetrigaon }\end{array}$ \\
\hline 35 & SHM (1250) & Moderate, & QIG 3 & $2.5-5 \mathrm{ka}$ & Inceptisols, Alfisols & -do- & - \\
\hline \multicolumn{8}{|c|}{ Ghaghara-Rapti Plains } \\
\hline 36 & SHM (1250) & Very weak & QIG 1 & $<0.5 \mathrm{ka}$ & Entisols & Srivastava et al., 1994 & - \\
\hline 37 & SHM (1250) & Weak & QIG 2 & $0.5-2.5 \mathrm{ka}$ & Inceptisols & -do- & - \\
\hline 38 & SHM (1250) & Moderate, & QIG 3 & $2.5-5 \mathrm{ka}$ & Inceptisols, Alfisols & -do- & - \\
\hline 39 & SHM (1250) & Weak & QIG 2 & $0.5-2.5 \mathrm{ka}$ & Inceptisols & -do- & - \\
\hline 40 & SHM (1250) & Strong & QIG 4 & $5-10 \mathrm{ka}$ & Alfisols & -do- & - \\
\hline 41 & SHM (1250) & Very strong & QIG 5 & $>10 \mathrm{ka}$ & Alfisols & -do- & - \\
\hline \multicolumn{8}{|l|}{ Gandak Megafan } \\
\hline 42 & SHM (1250) & Very weak & QIG 1 & $<0.5 \mathrm{ka}$ & Entisols & Srivastava et al., 1994 & - \\
\hline 43 & SHM (1250) & Moderate, & QIG 3 & $2.5-5 \mathrm{ka}$ & Inceptisols, Alfisols & Mohindra et al., 1992 & - \\
\hline 44 & SHM (1250) & Strong & QIG 4 & $5-10 \mathrm{ka}$ & Alfisols & -do- & - \\
\hline 45 & SHM (1250) & Moderate, & QIG 3 & $2.5-5 \mathrm{ka}$ & Inceptisols, Alfisols & -do- & - \\
\hline 46 & SHM (1250) & Weak & QIG 2 & $0.5-2.5 \mathrm{ka}$ & Inceptisols & -do- & - \\
\hline \multicolumn{8}{|l|}{ Gandak-Kosi Interfan } \\
\hline 47 & SHM (1250) & Very weak & QIG 1 & $<0.5 \mathrm{ka}$ & Entisols & Mohindra et al., 1992 & - \\
\hline 48 & SHM (1250) & Weak & QIG 2 & $0.5-2.5 \mathrm{ka}$ & Inceptisols & -do- & - \\
\hline 49 & SHM (1250) & Very weak & QIG 1 & $<0.5 \mathrm{ka}$ & Entisols & Mohindra et al., 1992 & - \\
\hline 50 & SHM (1250) & Moderate, & QIG 3 & $2.5-5 \mathrm{ka}$ & $\begin{array}{l}\text { Fluvenitc Endoquepts, Typic } \\
\text { Endoaqualfs, Entisols }\end{array}$ & Sinha and Friend, 1999 & Nanpur, Gaupur \\
\hline \multicolumn{8}{|l|}{ Kosi Megafan } \\
\hline & SHM (1250) & Very weak & QIG 1 & $<0.5 \mathrm{ka}$ & Entisols & Singh et al., 1993 & - \\
\hline \multicolumn{8}{|c|}{ Mahnanda-Tista Plains } \\
\hline 52 & HM (1750) & Weak & QIG 2 & $0.5-2.5 \mathrm{ka}$ & Inceptisols & Singh et al., 1998 & - \\
\hline \multicolumn{8}{|l|}{ Barind Tract } \\
\hline $53 a$ & HM (1583) & Moderate, & QIG 3 & $2.5-5 \mathrm{ka}$ & Inceptisols, Alfisols & Singh et al., 1998 & Alampur \\
\hline $53 \mathrm{~b}$ & HM (1750) & Strong & QIG 4 & $5-10 \mathrm{ka}$ & Alfisols & -do- & - \\
\hline \multicolumn{8}{|l|}{ Deltaic Plains } \\
\hline 54 & HM (1750) & Weak & QIG 2 & $0.5-2.5 \mathrm{ka}$ & Inceptisols & Singh et al., 1998 & Jodipur \\
\hline 55 & HM (1750) & Very strong & QIG 5 & $>10 \mathrm{ka}$ & Alfisols & -do- & - \\
\hline 56 & SHM (1404) & Strong & QIG 4 & $5-10 \mathrm{ka}$ & $\begin{array}{l}\text { Vertic Endoaqualfs, } \\
\text { ChromicVertic Endoaqualfs }\end{array}$ & -do- & $\begin{array}{l}\text { Tirula, Kondal Mauza, Manteshwar, Nasigram, } \\
\text { Hangram, Konapara, Madhpur, Sasanga }\end{array}$ \\
\hline 57 & SHM (1583) & Moderate, & QIG 3 & $2.5-5 \mathrm{ka}$ & Typic Endoaquerts & Pal et al., 2010 & Chunchura \\
\hline \multicolumn{8}{|c|}{ Tista-Brahamputra Plains } \\
\hline 58 & PH (2000) & Weak & QIG 2 & $0.5-2.5 \mathrm{ka}$ & Inceptisols & Aruche, 2014 & - \\
\hline 59 & PH (3292) & Moderate, & QIG 3 & $2.5-5 \mathrm{ka}$ & Typic Endoaqualfs & Pal et al., 2010 & Seoraguri \\
\hline 60 & $\mathrm{PH}(>2500)$ & Very weak & QIG 1 & $<0.5 \mathrm{ka}$ & Entisols & Aruche, 2014 & - \\
\hline 61 & $\mathrm{PH}(>2500)$ & Weak & QIG 2 & $0.5-2.5 \mathrm{ka}$ & Inceptisols & -do- & - \\
\hline 62 & $\mathrm{PH}(>2500)$ & Weak & QIG 2 & $0.5-2.5 \mathrm{ka}$ & Inceptisols & -do- & - \\
\hline
\end{tabular}


were stabilised during 2.5-5 ka (e.g. Units 1, 9, 16, 22, 30, 32, 35, 38, 43, $45,50,53 a, 57,59$; Fig. 1; Table 3 ). These are characterized by $50-80 \mathrm{~cm}$ thick Bw/Bt horizons. Thin sections of these soils show strongly developed subangular blocky structure, moderate to strong pedality, appreciable alteration of biotite and feldspar grains, and strongly developed cross-striated b-fabrics (Srivastava and Parkash, 2002). There is appreciable increase of illuvial clay with depth, occurring as thick (50$60 \mu \mathrm{m}$ ) clay coatings that accounts for $>1 \%$ in many soils (Srivastava and Parkash, 2002). Pedogenic carbonate commonly occurs as irregular shaped nodules of micrite in lower parts of the soils from western and central parts of the IGP. Soils of this geomorphic surface follow Inceptisols and Alfisols characteristics (Srivastava et al., 1994).

\subsection{QIG4 geomorphic surface and soils}

This geomorphic surface is defined by lower and middle parts of the major interfluves, old surfaces of mega fans, old river plains (units 2, 4, $6,10,23,33,40,44,53 b, 56$; Fig. 1; Table 3). Age of these soils suggest stabilisation of this surface occurred during 5-8 ka (Tables 1 and 2). The soils occurring over this surface are very mature with 75-100 cm thick Bt horizons. Thin section of these soils show strong pedality, strong alteration of mineral grains, and extensive domains of cross and reticulate striated b-fabrics (Srivastava and Parkash, 2002). Illuvial clay pedofeatures constitute $>1 \%$ of the thin sections and are 80 $100 \mu \mathrm{m}$ thick and microlaminated in nature. Pedogenic carbonate is common in soils of the interfluves as dense micritic nodules with dissolution and reprecipitation features. These soils belong to Alfisols characteristics (Table 3 ).

\subsection{QIG5 geomorphic surface and soils}

This geomorphic surface is defined by the most strongly developed soils of the IGP in interfluves, oldest piedmonts and old river plains (e.g. units 5, 8, 11, 24, 26, 29, 34, 41, 55; Fig. 1; Table 3). Age of this surface is assigned as $10-13.5 \mathrm{ka}$ on the basis of $\mathrm{C}^{14}$ and OSL dates (Table 2). This geomorphic surface is marked by $>100 \mathrm{~cm}$ thick Bt horizons with very strongly developed pedofeatures (Srivastava et al., 1994; Singh et al., 2006). Thin sections of the soils showed very strong pedality and extensive illuvial clay pedofeatures $(>1 \%)$ and pedogenic carbonate features of different phases. The clay pedofeatures are marked by thick 100-200 $\mu \mathrm{m}$ microlaminated clay coatings along the voids. Coarse mineral grains show strong alteration of biotite and feldspar grains. It is marked by very strong cross and reticulate striated b-fabrics. These soils belong to Alfisols characteristics (Srivastava et al., 1994).

\subsection{Significance of the geomorphic surfaces of the IGP}

The geomorphic surfaces identified over the entire IGP are similar to the geomorphic surfaces in interfluves of the Greenfield Quadrangle, Iowa defined by Ruhe $(1956,1969)$. Accordingly a geomorphic surface is defined as a portion of the landsurface comprising both erosional and depositional elements, having continuity in time and space. It may occupy appreciable part of the landscape and may include many landforms. It is established when a stable surface is first presented subaerial weathering and soil development (Ruhe, 1969). The geomorphic surfaces of the IGP are comparable to the post-incisive soil chronosequences marked by a sequence of progressively younger surfaces in which soils formation may begin (Vreeken, 1975; Mohindra et al., 1992; Srivastava et al., 1994; Huggett, 1998). The geomorphic surfaces are potentially useful to comprehend the pedogenic response of the IGP soils to climate change, neotectonics, and factors of the soil formation (cf. Sections 3-5).

\subsection{Soil-geomorphic groups of the IGP}

A soil-geomorphic group consists of several soil-geomorphic units that occur adjacent to each other within a region bound by different rivers or other landforms. In field, a soil-geomorphic group could be identified as grouping of distinctly different soils on different components of a landform or the adjacent landforms bound by major rivers. For example, the Ganga-Ghaghara Interfluve (GGI) is a group of 11 soil-geomorphic units (i.e. Units 25-35; Fig. 1; Table 3). Based varying pedogenic development in these units five geomorphic surfaces (QIG1-QIG5) are identified in the GGI (Table 3). Following this criteria, the 62 soil-geomorphic units of the IGP are organised in to 12 soil-geomorphic groups that are defined as: (1) Ravi-Ghagghar Plains (RGP), (2) Ghagghar-Yamuna Plains (GYP), (3) Yamuna-Ganga Interfluve (YGI), (4) Ganga-Ghaghara Interfluve (GGI), (5) Ghaghara-Rapti Plains (GRP), (6) Gandak Megafan (GMF), (7) Gandak-Kosi Interfan (GKI), (8) Kosi Megafan (KMF), (9) Mahananda-Tista Plains (MTP), (10) Barind Tract (BT), (11) Deltaic Plains (DP), and (12) Tista-Brahmaputra Plains (TBP). A synthesis of the soils for the entire IGP spread over 62 soilgeomorphic units and the 12 soil-geomorphic groups is presented in Table 3. A brief description of the 12 soil-geomorphic groups with different geomorphic surfaces (QIG1-QIG5) is presented below. It highlights the role of soil development on different geomorphic surfaces in response to climate change and neotectonics.

\subsubsection{Ravi-Ghagghar Plains (RGP)}

This soil-geomorphic group defines the western most part of the IGP, between the Ravi River and the Ghagghar River and is marked by westerly drainage. The RGP includes eleven soil-geomorphic units (Units 1-11, Fig. 1; Table 3) dominated by well-developed soils that belong to QIG4-QIG5 surfaces (5.0-10 ka, >10 ka) for most parts of the RGP. The RGP is also marked by few weakly and moderately developed soils (QIG1: e.g. units 3 and 7, QIG3: e.g. unit 9; Table 3 ) in the areas of active sedimentation like floodplains, piedmonts, and interfluves (Fig. 1). The dominance of Alfisols and Inceptisols in the RGP indicates moderate-strong degree of development on QIG3-QIG5 surfaces (Sehgal, 1974; Pal et al., 2009b, 2010).

\subsubsection{Ghagghar-Yamuna Plains (GYP)}

The GYP is the major geomorphic divide that separates fluvial plains with westerly drainage (Ravi, Beas, Sutluj, and Ghagghar Rivers) from easterly drainage (Yamuna, Ganga, Ghaghara Rivers) systems. It is characterized by weakly developed soils (QIG2: Inceptisols; $0.5-2.5 \mathrm{ka}$ ) that also forms an important soil-geomorphic divide between the welldeveloped soils (QIG4-QIG5: 5-10 ka: Alfisols) on either sides of the GYP (Fig. 1). Seven soil-geomorphic units identified over the GYP occur on uplands between the Ghagghar and Yamuna rivers, the Aeolian Plains, and the Old Yamuna Plains (units 12-17; Fig. 1; Table 3). Soils in the GYP are characterized by weakly developed profiles with Inceptisols in $>90 \%$ of the area (Singhai et al., 1991; Pal et al., 2010; Aruche, 2014).

\subsubsection{Yamuna-Ganga Interfluve (YGI)}

The YGI occurs to the immediate east of the soil-geomorphic divide, the GYP. It is one of the largest soil-geomorphic groups with upland interfluve between the Ganga and the Yamuna rivers (Fig. 1). It consists of six soil-geomorphic units that are dominated by well developed soils with predominance of Alfisols on QIG3-QIG5 surfaces (units 19-24; Fig. 1; Table 3). The northern most part of the YGI is characterized by incised piedmonts and the oldest soil on QIG5 surface (Kumar et al., 1996).

\subsubsection{Ganga-Ghaghara Interfluve (GGI)}

Similar to the YGI, the interfluve between the Ganga and the Ghaghara Rivers comprises a very large part of the IGP. It is made up of 11 soil-geomorphic units (units 25-35; Fig. 1 ; Table 3). More than $>50 \%$ of the soils in the GGI occur on the oldest geomorphic surface (QIG5: $>10 \mathrm{ka}$ ). In the northern most part of the GGI, immediately below the 
foothills, it is marked by young soils on alluvial fans and fluvial plains (QIG1-QIG3 surfaces: Srivastava et al., 1994; Singh et al., 2006). A major part of the GGI, approximately $60-80 \%$ is dominated by Alfisols (Srivastava et al., 1994; Pal et al., 2010).

\subsubsection{Ghaghra-Rapti Plains (GRP)}

The GRP occurs to the east of GGI and it is marked by upland interfluve, fluvial plains and piedmonts between the Ghaghara and the Rapti Rivers (Srivastava et al., 1994). About $40-50 \%$ of the GRP is covered by young soils on QIG1-QIG3 surfaces and 50-60\% old the soils on QIG4-QIG5 surfaces (Srivastava et al., 1994). The northern part of the GRP is characterized by incised piedmont with QIG1 and QIG2 surfaces and numerous paleochannels of the Ghaghara River with QIG1 soils (Srivastava et al., 1994).

\subsubsection{Gandak Megafan (GMF)}

The GMF is one of the largest wet alluvial fans of the world that occurs in central part of the IGP. It is marked by an $80 \mathrm{~km}$ shift of the Gandak River over the last $5 \mathrm{ka}$ (Mohindra et al., 1992). It consists of five soil-geomorphic units that show an increase in the degree of soil development from east to west with oldest soils on QIG4 surfaces (units 42-46; Fig. 1; Table 3).

\subsubsection{Gandak-Kosi Interfan (GKI)}

The GKI is a geomorphic low with active sedimentation between the Gandak megafan in the west and the Kosi megafan in the east. Four soil-geomorphic units, making up the GKI, contain predominantly weakly developed soils on QIG1-QIG2 surfaces (units 47 and 48; Fig. 1; Table 3). Some of the soils in the middle part of the interfan show moderate development on QIG3 surface (units 49 and 50; Fig. 1; Table 3).

\subsubsection{Kosi Megafan (KMF)}

The tear drop shaped KMF is the largest wet alluvial fan in the world with a diameter of about $120 \mathrm{~km}$ and area of $\sim 16,000 \mathrm{~km}^{2}$. It is marked by $>110 \mathrm{~km}$ westward shifting of the Kosi River channel over the last 220 years (Wells and Dorr, 1987; Singh et al., 1993). Facies analysis of the KMF shows rapid sedimentation (Singh et al., 1993). It mainly consists of very weakly developed soils that correspond to QIG1 surface of the IGP (Singh et al., 1993).

\subsubsection{Mahananda-Tista Plains (MTP)}

The MTP lying immediately in the east of the Kosi megafan is limited by piedmont in the north and fluvial plains of Mahananda and Tista Rivers in the south. Soils of the MTP are characterized by weakly developed soils as Entisols and Inceptisols on the QIG1-QIG2 surfaces (NBSSLUP, 1992; Singh et al., 1998).

\subsubsection{Barind Tract (BT)}

The BT is marked by uplifted region in the south of MahanandaTista Plains. This is associated with an east-west trending upland with its major portion in Bangladesh. At least three topographic levels with height ranging from 5 to $25 \mathrm{~m}$ above the adjoining floodplains occur on the Barind Tract (Singh et al., 1998). The associated soils shows predominance of Inceptisols and Alfisols developed on QIG3-QIG4 surfaces (units 53-54; Fig. 1; Table 3).

\subsubsection{Deltaic Plains (DP)}

The deltaic plains (DP) are marked by the uplands of the Chhotanagpur-Rajmahal Hills (35-120 m msl) and the old and young fluvial plains (Units 54-56; Fig. 1; Table 3). The landscape is very gently sloping to undulating with dendritic and annular drainage and red soils (Singh et al., 1998). Soils of the upland show strong pedogenic development with dominance of ferruginous Alfisols on the QIG5 surfaces (Singh et al., 1998; Aruche, 2014). The Old fluvial/deltaic Plains, located to the east of the upland area, are levelled with ferruginous soils. The plains include the Bhagirathi-Ajay Plains, the Ajay-Silai Plains and Damodar-Deltaic Plain that contain weak to moderately developed Inceptisols, Alfisols, and Vertisols (Singh et al., 1998; Pal et al., 2010; Aruche, 2014).

\subsubsection{Tista-Brahmaputra Plains (TBP)}

The TBP demarcates the eastern most part of the IGP with piedmont and fluvial plains (units 58-62; Fig. 1; Table 3). It is marked by westward flowing braided channel of the Brahmaputra River and numerous small alluvial fans and piedmonts below the foothills (Fig. 1). Active sedimentation over this area shows the dominance of only weakly developed soils as Entisols and Inceptisols on QIG1 and QIG2 surfaces and moderately developed soils on QIG3 surfaces (units 58-62; Fig. 1; Table 3).

\subsection{Field characteristics of soils across the IGP}

Field characteristics of the 4 representative pedons across the IGP are distinguishable by soil texture, Bw/Bt horizon thickness, and pedogenic carbonates (Fig. 2). The soils over the western part of the IGP beyond the Yamuna river show coarse texture, thin $\mathrm{Bw} / \mathrm{Bt}$ horizon with large amount of pedogenic carbonates (e.g. Pedon Khambi, Fig. 2), but the soils over the central parts in interfluve regions are marked by sandy to silty clay loam with thick Bt horizons and less pedogenic carbonates (e.g. Pedons Sasni and Dodapur, Fig. 2). The soils over the eastern most part in the deltaic region are marked by fine silty clay to clayey texture, vertic features, and absence of pedogenic carbonates (e.g. Pedon Manteshwar, Fig. 2).

\subsection{Soil Ages of the IGP}

The IGP was considered to consist of an older and a younger alluvium. Marked by a higher degree of pedogenesis, the older alluvium was assigned a lower Pleistocene age (Wadia, 1966; Bhattacharya and Banerjee, 1979) or a minimum age of $120 \mathrm{ka}$ (Singh, 1988). Recent soil-geomorphic studies demonstrate the presence of more than two geomorphic surfaces in the IGP (Mohindra et al., 1992; Srivastava et al., 1994, 1998; Kumar et al., 1996; Singh et al., 1998). Age of the IGP soils that formed on five geomorphic surfaces range from $<0.5 \mathrm{ka}$ to $13.5 \mathrm{ka}$ (Tables 1 and 2). The soil ages are based on radiocarbon, thermoluminescence (TL), archaeological, and historical data from the IGP (Table 2). The TL dates are greater than the radiocarbon dates of calcretes (Table 2). This is due to the fact that TL dates give the time of deposition and start of pedogenesis, whereas calcrete takes time to form and it is also affected by dissolution and reprecipitation within the soil profile (Srivastava et al., 1994; Singh et al., 1998). TL dates are considered here as approximate maximum ages of soils. The Lateritic Upland (unit 55, Fig. 1) with red soils of Early to Middle Pleistocene age is the oldest soil of the IGP (Singh et al., 1998).

\section{Holocene climatic fluctuations and pedogenic response of IGP soils}

The soil-geomorphic research during the last two decades has helped in delineating the paleoclimatic record of the IGP during the Holocene. It also establishes the use of micromorphology, clay minerals, isotope geochemistry of pedogenic carbonates, and polygenetic pedogenic features as important proxies for Holocene climate changes (Srivastava et al., 1998; Srivastava, 2001; Srivastava and Parkash, 2002). Information from these proxies indicates two humid phases during soil formation over the IGP, one between $13.5 \mathrm{ka}$ and $11.0 \mathrm{ka}$ and the other between $6.5 \mathrm{ka}$ and $4.0 \mathrm{ka}$. The intervening period witnessed the dry climate (Srivastava et al., 1998; Pal et al., 2000a; Srivastava, 2001; Srivastava and Parkash, 2002).

Micromorpholological studies reveal that soils of the IGP are polygenetic (Srivastava and Parkash, 2002). The QIG5 soils on uplands are 
marked by degraded illuvial clay pedofeatures of an early humid phase $(13.5 \mathrm{ka}-11.0 \mathrm{ka})$ and thick $(150-200 \mu \mathrm{m})$ microlaminated clay pedofeatures of a later humid phase $(6.5-4.0 \mathrm{ka})$. The earlier clay pedofeatures show degradation as bleaching, loss of preferred orientation, development of a coarse speckled appearance and fragmentation, whereas those of the later phase are thick, smooth and strongly birefringent microlaminated clay pedofeatures (Srivastava and Parkash, 2002). The illuviation was more extensive during the later phase, as indicated by enrichment of groundmass as discrete pedofeatures of clay intercalations.

The dry phases of climate (early Holocene to $6.5 \mathrm{ka}$ and after $4.0 \mathrm{ka}$ ) show dominance of the pedogenic carbonate (PC) formation and their dissolution-reprecipitation in the subsequent wetter conditions (Srivastava, 2001; Srivastava and Parkash, 2002). Clay mineralogical studies of IGP soils show that biotite weathered to trioctahedral vermiculite and smectite during the semiarid-arid conditions and it transformed to interstratified smectite-kaolin $(\mathrm{Sm} / \mathrm{K})$ during the warm and humid conditions (Srivastava et al., 1998). The relatively dry climates since $4.0 \mathrm{ka}$ lead to the preservation of vermiculite, smectite, and Sm/ K assemblages in older soils of the IGP (Srivastava et al., 1998). The Carbon and Oxygen isotope studies on the pedogenic carbonates from the older soils (8-10 ka) reveal a relative depletion of ${ }^{13} \mathrm{C}$ in comparison with younger soils $(<2.5 \mathrm{ka})$, indicating low soil-respiration and drier conditions during the early Holocene (Srivastava, 2001). The paleoclimatic changes inferred through pedogenic carbonate of the IGP soils are consistent with those reflected by the paleovegetation record (Gupta, 1978; Srivastava, 2001). The Holocene paleovegetation information from the IGP indicates the spread of Chenopodium and Typha angustata biomass during the semiarid-arid climate that changed to Anogeissus and Tecomella spp. in warm and humid phase of climate (Gupta, 1978).

\section{Neotectonics and pedogenic response of IGP soils}

The tectonic framework of the vast and flat IGP can be organised as basement and surface structural features. The basement structural features of the IGP extend as major transverse faults, ridges, and depressions (Fig. 3). The surface structural features are the faults and tectonic blocks that are deciphered by mapping of soilgeomorphic units and the drainage pattern in the IGP (Fig. 4). Some of the surface faults are related to the basement and these have been active over the last $10 \mathrm{ka}$. These faults in the IGP are considered analogues to the growth faults in the deltaic regions (Mohindra et al., 1992; Srivastava et al., 1994; Singh et al., 1998). The neotectonic structures are marked as surface ruptures as normal faults and thrust splays that show topographic breaks up to $20 \mathrm{~m}$ (Srivastava et al., 1994; Parkash et al., 2000; Pati et al., 2012). Development of the surface structural features in the IGP is mainly due to the movement of the Indian Plate, causing compressive stresses from the $555^{\circ} \mathrm{W}$ direction (Srivastava et al., 1994; Parkash et al., 2000).

The pedogenic response of the IGP to neotectonics is described here. In the western part of the IGP, soils on two sides of the Ghagghar River are very different in terms of degree of soil development. In its western side, the soils are marked by well developed features on QIG3-QIG5 surfaces in the Punjab, while on eastern side it is marked by weakly developed soils on QIG2 surface in the Haryana. The contrasting nature of the soils on two sides of the Ghagghar River is due to the presence of a transverse fault along the Ghagghar River (Fig. 4; Singhai et al., 1991). The upland in west of the Ghagghar river is related to shifting of Sutluj river with many paleochannels (Pal et al., 1980). The Yamuna River is related to a fault along its course due to down warping in its west and reactivation of a major fault, i.e. Sohna-Sonipat fault (Garlapuri, 1984). Kumar et al. (1996) mapped this fault based on soil geomorphic development and contrasting soils on either sides and interpreted that this fault represents a fault system with convexity towards southwest (Fig. 4). Similarly, the Ganga River in middle part of the IGP runs along a fault system with convexity towards west (Srivastava et al., 1994; Kumar et al., 1996). This fault system is also demarcated by contrasting soils on either side of the Ganga River (Srivastava et al., 1994; Kumar et al., 1996). The Yamuna Fault and the Ganga Fault merge in the south with similar upland soils on either side (e.g. QIG5 soils in units 24 and 34; Fig. 4). The Ghaghara fault system demarcates boundaries between upland interfluve in the east and the west of the river (Srivastava et al., 1994).

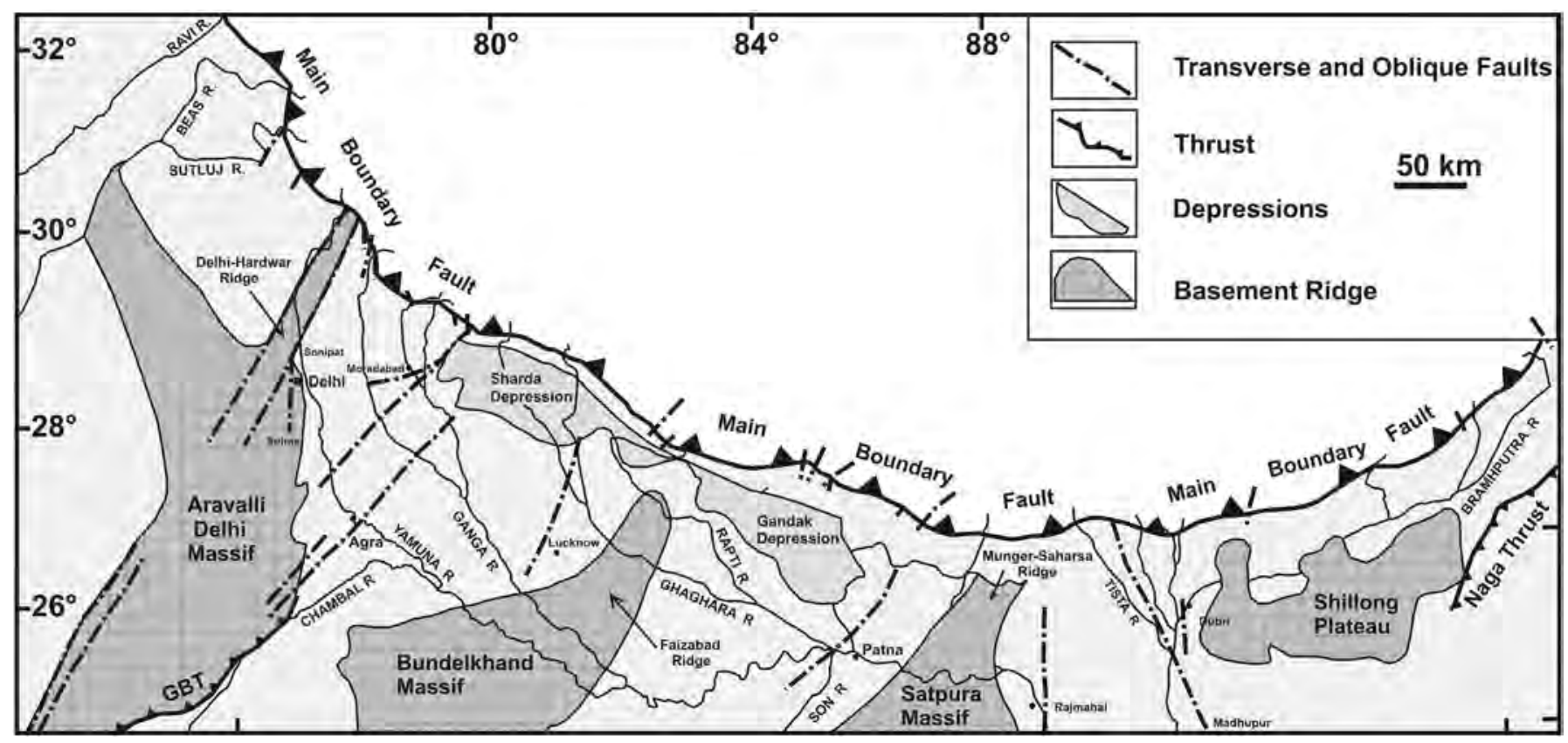

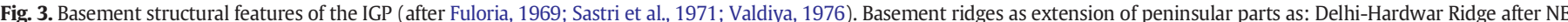

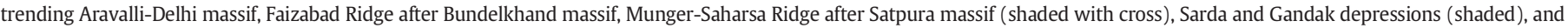

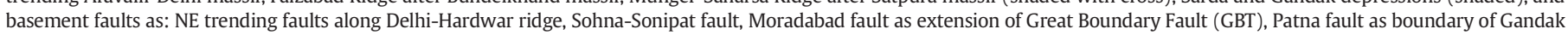
Depression and Munger-Saharsa ridge, Dubri Fault between Assam Plateau and Bengal basin, and growth faults of the Bengal basin. 


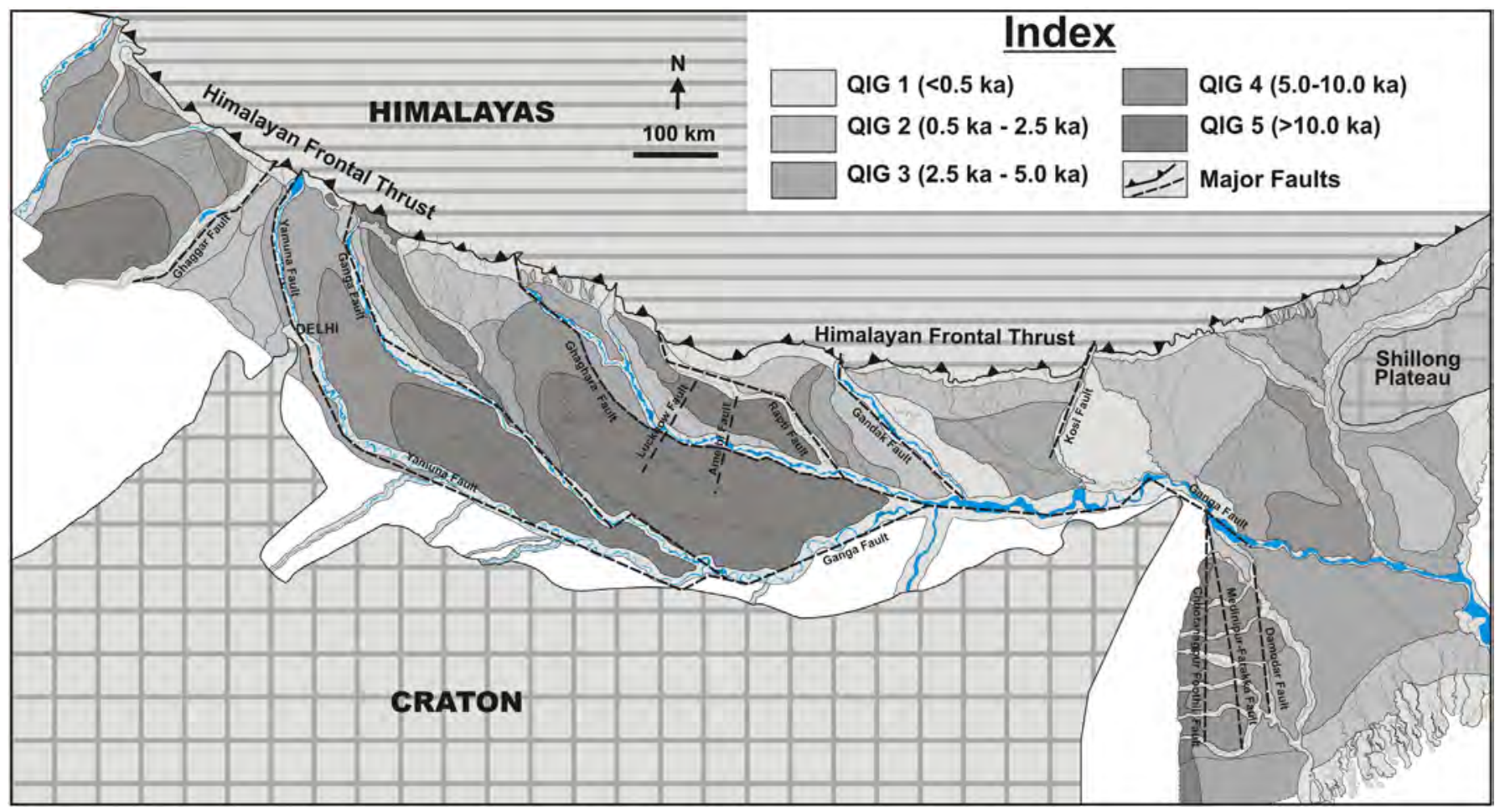

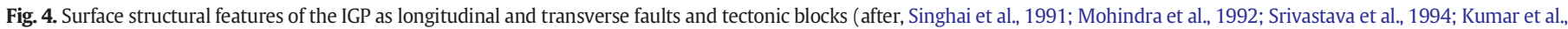
1996; Singh et al., 1998).

Two transverse faults, the Lucknow and the Amethi faults, broadly coincide with the Faizabad basement ridge (Figs. 3 and 4). The two faults have resulted in segmentation of the interfluves over this region (Srivastava et al., 1994). The Gandak River has shifted $\sim 80 \mathrm{~km}$ to east in the last 5 ka due to tilting of the megafan (Mohindra et al., 1992). Contrasting soils on either side of the Gandak megafan are due to Rapti and Gandak Faults that are unrelated to any basement feature of the region (Mohindra et al., 1992). The interfan between Gandak megafan and Kosi megafan is marked by muddy sequences with rapid sedimentation (0.7-1.5 mm/a) and weakly developed soils (Sinha and Friend, 1999). The fault along the Kosi River is a sinistral fault that offsets the Siwalik sediments for about $20 \mathrm{~km}$. It broadly coincides with a major transverse fault with down warping in the west (Raiverman et al., 1983). The soils over the deltaic region of the IGP occur within Bengal Sedimentary Basin bordering cratonic rocks (unit 55, Fig. 1). Singh et al. (1998) mapped soil-landscapes of the area and delineated three transverse faults, Chhotanagpur foothill fault (CFF), MedinapurFarakka fault (MFF), and Damodar fault (DF) bounding tectonic blocks (Fig. 4). The landforms over the three tectonic blocks are marked by $25 \mathrm{~m}, 20 \mathrm{~m}$, and $6 \mathrm{~m}$ topographic relief with a down-throw towards east (Singh et al., 1998). In an earlier study, a series of N-S trending basement faults were reported as Basin Margin Faults in this region (Sen-Gupta, 1966).

The pedogenic response to the neotectonics in the IGP can be explained by tectonic movement of the fault bounded blocks (Srivastava et al., 1994). Uplift of the blocks above the general level of rivers led to the termination of sedimentation and initiation of pedogenic activity. Soils formed on the uplifted blocks, therefore, preserve the climate record. The uplift of different blocks at different times provides a sequence of soils that preserve signatures of the climate and the extent of soil development. The older soils are also modified by the later climate showing polygenetic features (Srivastava and Parkash, 2002). In view of the neotectonics of the IGP, following features within soils and geomorphic units need to be highlighted: (i) Nearly $50 \%$ of the IGP is covered by upland region with well developed soils on QIG4 - QIG5 surfaces in western part of the Ghagghar, upland interfluves of the YamunaGanga, Ganga-Ghaghara, Ghaghara-Rapti interfluves and some upland regions of the deltaic plains (unit 55-56, Fig. 1). It implies strong pedogenic activity since $\sim 10$ ka over these stable upland regions and active sedimentation in the remaining parts of the IGP with poorly developed soils (Srivastava et al., 1994; Kumar et al., 1996; Singh et al., 1998). (ii) Sagging or down warping of large geomorphic surfaces or tectonic blocks bounded by faults resulted in greater sinuosity of the streams such as, the Gomti, Sai, Rapti and Sarju rivers in units 34, 401, 41; (Figs. 1 and 4 after Srivastava et al., 1994). (iii) The compressive forces from SW, most likely played a key role in modifying the otherwise flat terrain to micro-low (0.5-1.0 m) and micro-high. It also influenced pedogenesis with dominance of highly sodic soils (Natrustalfs/ Natraqualfs) in micro-low and less sodic soils over micro-high areas (Pal et al., 2003a).

\section{Soils of the IGP: climatic variability, pedogenic processes, and taxonomic classes}

\subsection{Climatic variability and soils of the IGP}

Soils of the IGP are spread across the seven climatic zones varying from hot-arid in the west to per humid conditions in the east (Fig. 5; Table 3). The soils in the western part of the IGP with hot-arid climate are marked by sandy loam texture and low organic carbon (OC). These soils are calcareous and moderately alkaline nature but not sodic due to less leaching and aridity (e.g. 4 benchmark soils; Table 3; Pal et al., 2010). Further east, the soils in semi-arid dry (SAD) climate are characterized by loam to sandy clay texture, low OC, calcareous, and neutral to moderate alkaline nature (e.g. 9 benchmark soils; Table 3; Pal et al., 2010). Some of the SAD soils are also sodic in nature (Pal et al., 2010). In the central and eastern part of the IGP with subhumid dry (SHD) and sub-humid moist (SHM) climate, the soils are characterized by silty loam to silty clay loam texture, low OC, moderate alkanity, and less calcareous nature (e.g. 14 benchmark soils; Table 3; 


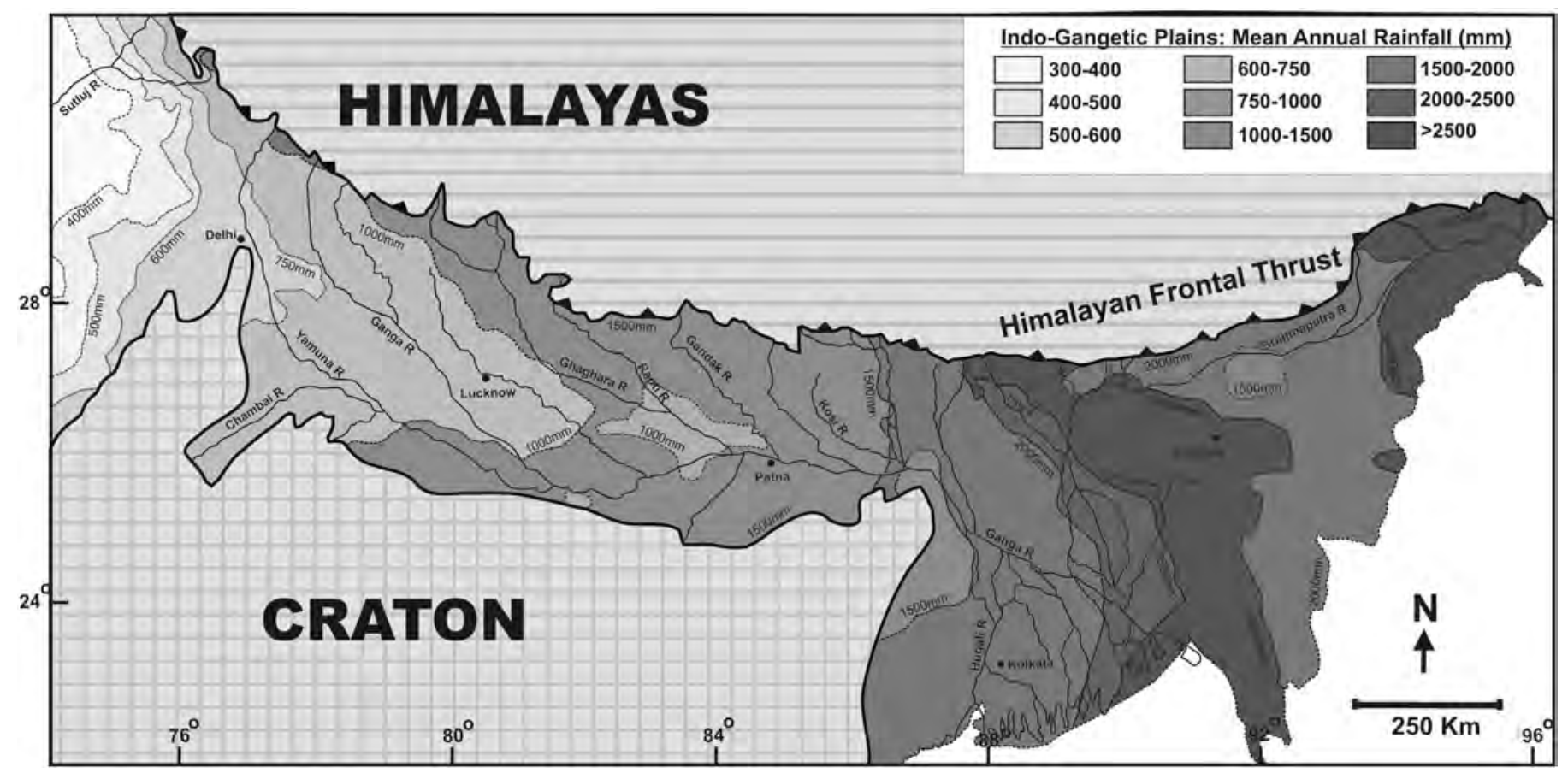

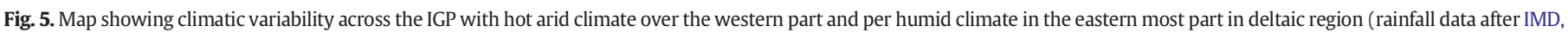
2009). The climatic zones stand for: HA-hot arid, SAD-semiarid dry, SAM-semiarid moist, SHD-sub humid dry, SHM-sub humid moist, HM- humid moist, PH- per humid.

Pal et al., 2010). In the southernmost part of the deltaic plains with humid moist (HM) climate, the soils are marked by silty clay to silty clay loam texture, high $\mathrm{OC}$, and saline-alkaline nature (e.g. 1 benchmark soil; Table 3; Pal et al., 2010). Soils over the Tista-Brahmaputra Plains (TBP) are characterized by per humid climate $(\mathrm{PH})$, silty clay loam to sandy clay loam texture, high $\mathrm{OC}$, slight acidity, and no pedogenic $\mathrm{CaCO}_{3}$ (e.g. 2 benchmark soils; Table 3; Pal et al., 2010). The prevailing climatic variability across the entire IGP plays a key role in the contemporary pedogenesis. It also influenced soils on older geomorphic surfaces with polygenetic features (Srivastava and Parkash, 2002; Pal et al., 2010).

\subsection{Pedogenic processes and taxonomic classes of soils in IGP}

The major pedogenic processes in soils of the IGP are addition and depletion of organic carbon (OC), formation of pedogenic $\mathrm{CaCO}_{3}$ (PC), illuviation of clay particles, and argilli-pedoturbation during the Holocene (Pal et al., 2000a,b, 2003b; Srivastava, 2001). The pedogenic processes resulted in formation of Entisols, Inceptisols, Alfisols and Vertisols with varying climate and parent material across the IGP. The PC occurring as powdery to large nodules (Fig. $6 \mathrm{a}-\mathrm{h}$ ), is marked by a general decrease in subsoils from hot arid to sub humid climates (Pal et al., 2000a; Srivastava, 2001). The PC is even absent in soils of per humid regions (e.g. Seoraguri soils, unit 59, Fig. 1). In western part of the IGP, the soils with Entisols and Inceptisols characteristics formed on QIG1 and QIG2 surfaces with large amount of PC in the soil profiles due to aridity. The Alfisols commonly occur in all climatic zones and correspond to QIG4 and QIG5 geomorphic surfaces of the IGP. In hot-arid and semiarid dry climates such soils are highly alkaline and mostly sodic in nature (Haplargidic/ Typic/Vertic Natrustalfs), whereas in SAM, SHD, SAM and PH climates, the soils become mildly alkaline, neutral-acidic, and non-sodic in nature (Oxyaquic/Typic Haplustalfs, Aeric/Vertic/Typic/Umbric Endoaqualfs) (Pal et al., 2010). The increased flux of cratonic origin enriched with plagioclase and smectitic clay as its weathering product has resulted vertic features in many soils over western and eastern parts of the IGP (Figs. 6g, h) (Pal et al., 2010; Aruche, 2014).

Most of the IGP soils, except than those with vertic characters, are marked by weathering of biotite on a large scale (Pal et al., 1994, 2003a; Srivastava et al., 1998; Srivastava and Parkash, 2002). Instead of pure void argillans, impure clay pedofeatures (Figs. 7a-f) with impairment of parallel orientation of clay platelets along the voids are typical of these soils (Pal et al., 1994, 2003b, 2009a, 2010). The presence of clay pedofeatures in soils with vertic characters (Fig. $7 \mathrm{~g}, \mathrm{~h}$ ) implies that clay illuviation is an important pedogenic process even in soils with shrink-swell pehenomena (Pal et al., 2009a, 2012b). Presence of illuvial clay features together with PC in soils indicates that illuviation of clay particles, especially in dry climates occurred under a favourable $\mathrm{pH}$ condition. That was favoured by higher than the zero point of charge required for complete dispersion of clay caused by the precipitation of soluble $\mathrm{Ca}^{2+}$ ions as $\mathrm{CaCO}_{3}$ (Eswaran and Sys, 1979). This discounts any role of soluble $\mathrm{Ca}^{2+}$ ions and the presence of $\mathrm{CaCO}_{3}$ in preventing the movement and the accumulation of clay particles. Thus the formation of illuvial clay pedofeatures and the pedogenic carbonates are two pedogenetic processes that occurred simultaneously during the formation of the IGP soils. The two contemporary pedogenetic events that cause concomitant development of soil sodicity exemplify the pedogenic threshold in dry climates during the Late Holocene (Pal et al., 2003b, 2009a, 2012b).

The Holocene climatic changes caused polypedogenesis in soils that formed on QIG 4 and QIG5 surfaces of the IGP (Srivastava and Parkash, 2002). Such soils over the western part with arid and semi arid climatic zones are marked by several episodes of pedogenic carbonates features together with illuvial features (Srivastava and Parkash, 2002). By contrast, the polypedogenic features in soils of the sub-humid to humid central and eastern parts of the IGP are dominated by the illuvial features over the pedogenic carbonates of different phases (Srivastava and Parkash, 2002).

The reclamation and amelioration practices have caused notable changes in the soil characteristics of the IGP. For example, the Sakit soils which were sodic (Murthy et al., 1982); following reclamation with gypsum and rice as first crop the soils now qualify as Haplustalfs (unit 23; Table 3). However, two soils, namely, Zarifa Viran and Hirapur still remain as sodic soils (Natrustalfs: unit 23 and 13; Table 3). Similarly, Haldi soils which were Mollisols (Murthy et al., 1982); after about two-and-half decades of agricultural practices qualify as Typic Haplustalfs (Unit 27; Table 3). 

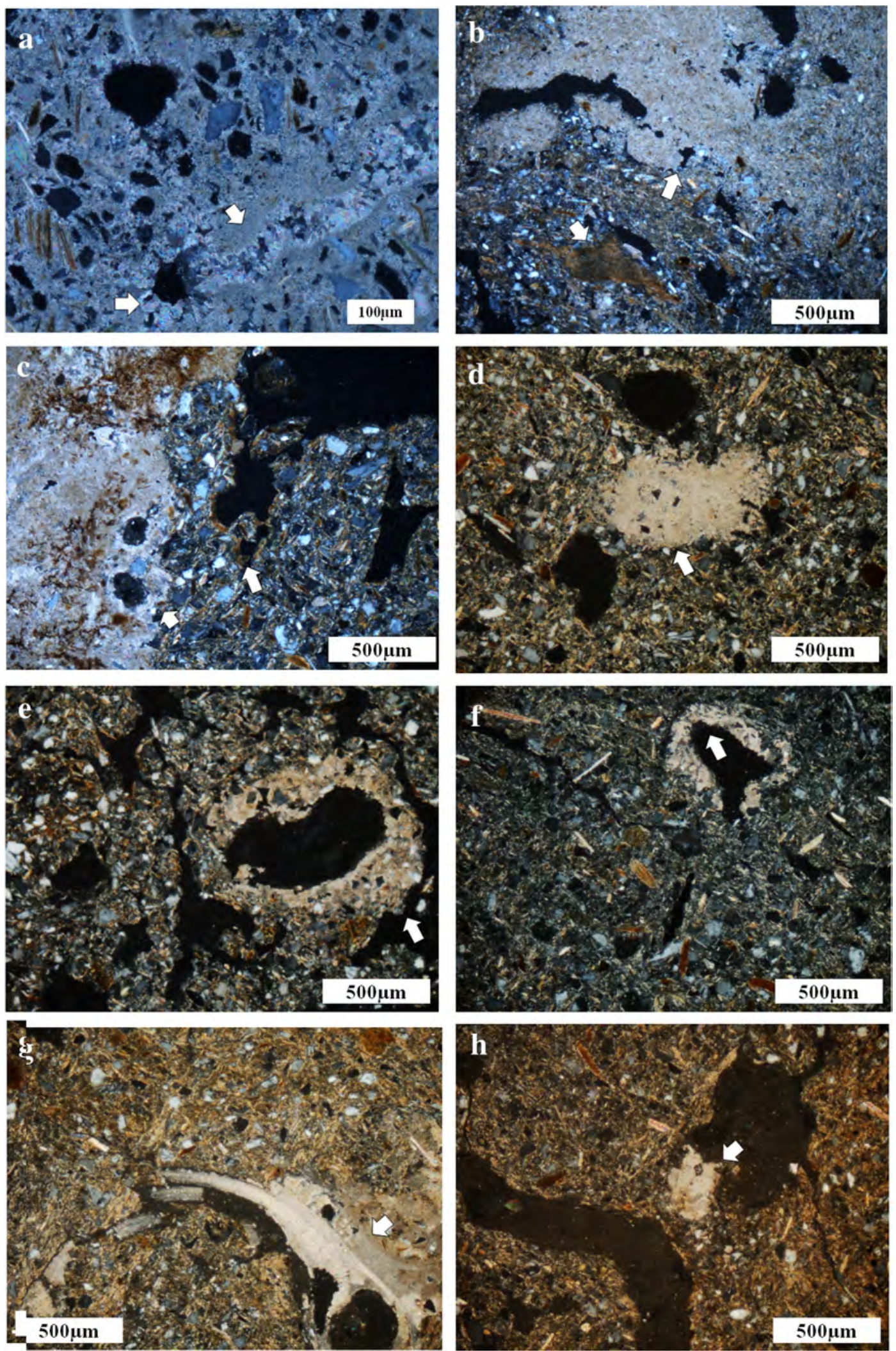

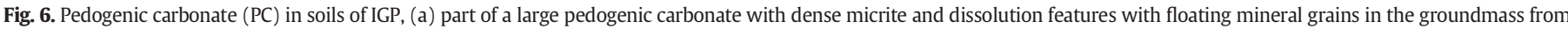

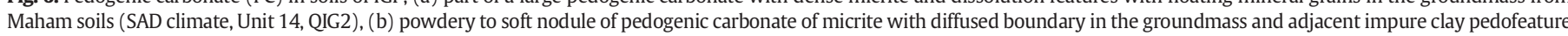

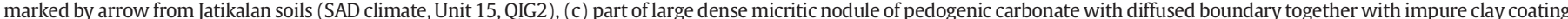

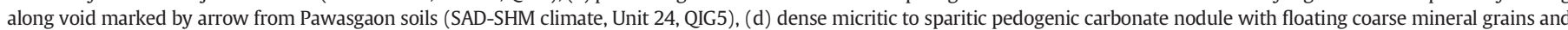

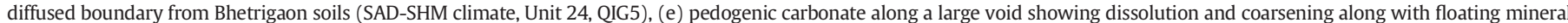

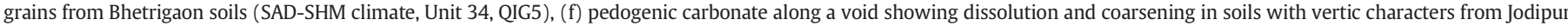

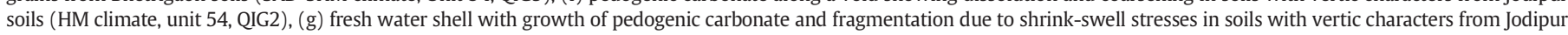
soils (HM climate, Unit 54, QIG2), (h) dissolution-coarsening of PC caught in a large void in soils with vertic characters from Jodipur soils (HM climate, Unit 54, QIG2). 

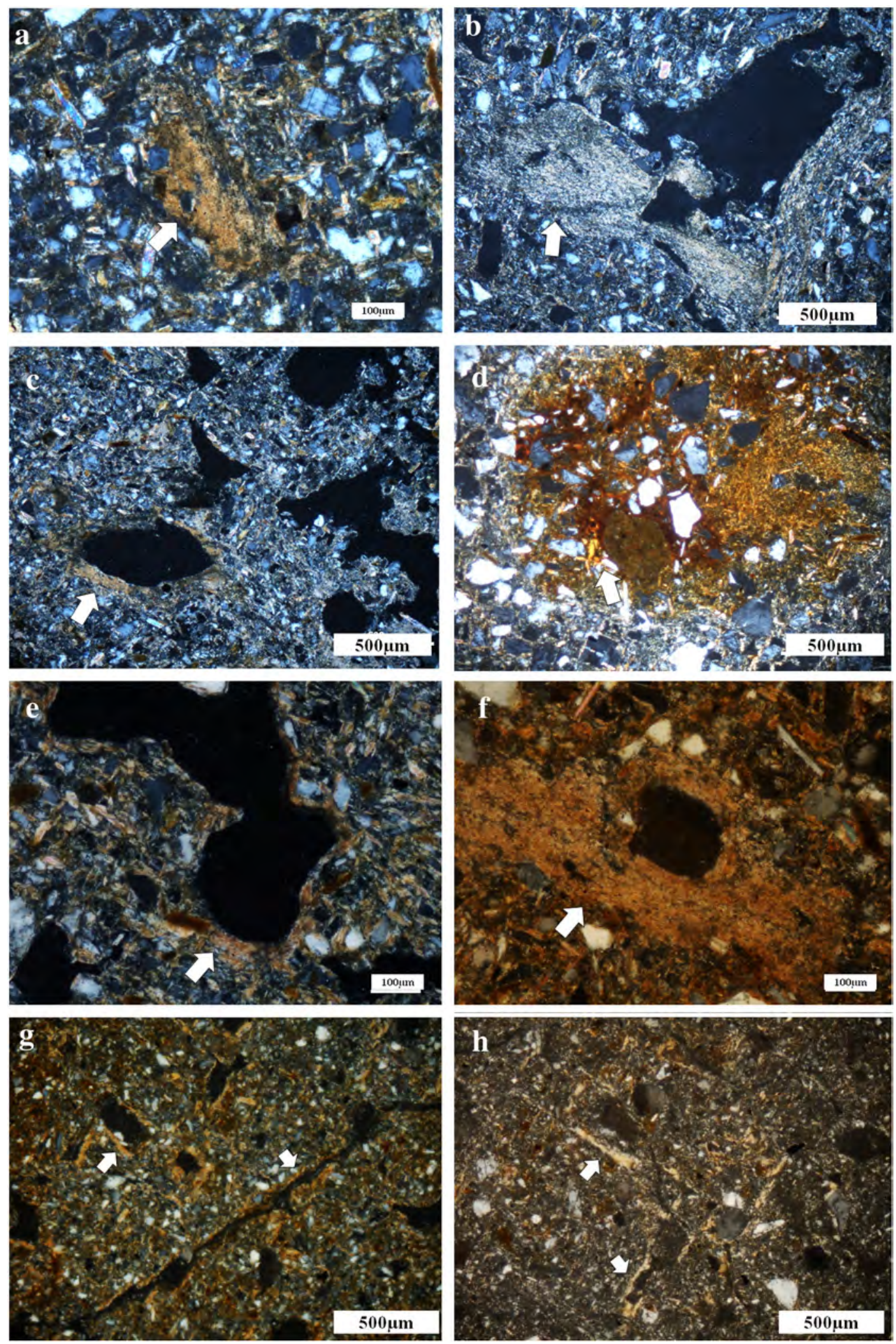

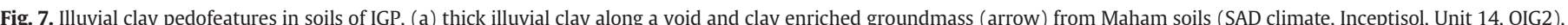
(b) impure clay coating (arrow) along a large irregular void from Nonand soils (SAD climate, Inceptisol, Unit 15, QIG2), (c) impure clay coatings along voids (arrow) from Jattari soils (SAD climate, Alfisol, Unit 23, QIG4), (d) large amount of impure clay intercalations in the groundmass marked by arrow from Hanumanta soils (SAD-SHM climate, Unit 24, QIG5), (e) impure clay coating along a large void from Narayanpur soils (SAD-SHM moist climate, Unit 34, OIG5), (f) thick impure clay coating along a large void from Atardihan soils (SHDSHM climate, Alfisols Unit 34, QIG5), (g) illuvial clay coatings along planar voids of the soils with vertic characters from Alampur soils (SHM climate, Unit 54, QIG2), (h) illuvial clay coatings along planar voids of the soils with vertic characters from Tirula soils (SHM climate, Unit 56, QIG4). 


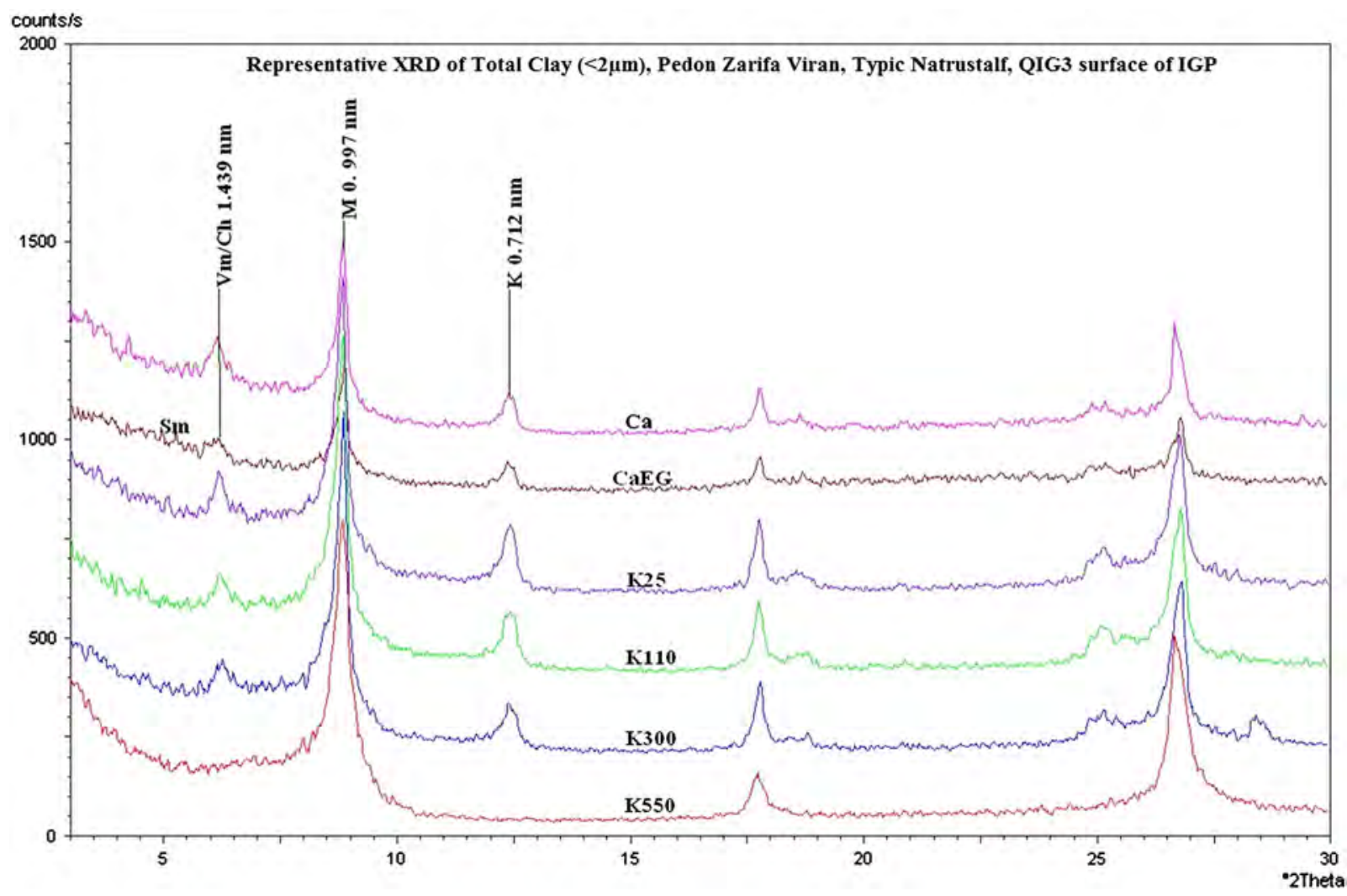

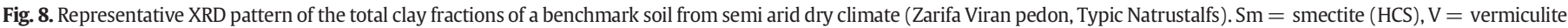

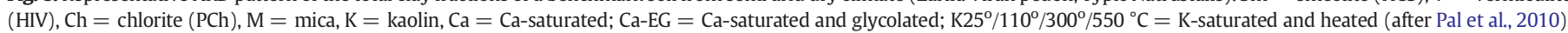

\subsection{Mineralogical Class of soils in IGP}

Majority of the IGP soils have micaceous mineralogy (e.g. Fig. 8; Zarifa Viran Pedon, unit 16), whereas the soils with the vertic character are smectitic. It is observed that smectitic Vertisols and its vertic intergrades appear not to have originated from the micaceous minerals (units 5 and 56; Fig. 1; Table 3). Had micas weathered to so much amount of smectite in these soils, all other non-vertic soils should also have smectitic mineralogy. The formation of the vertic characters in the soils of the IGP can be explained in view of the non micaceous sedimentary flux of cratonic origin (Pal et al., 2012a). Micromorphological and mineralogical investigations indicate that dominance of the cratonic flux enriched with plagioclase and smectitic clay contributed to the vertic characters in these soils (Singh et al., 1998; Pal et al., 2010; Srivastava et al., 2010; Aruche, 2014). The alluvium of the Himalayan origin contains considerably less smectite as compared to that of the craton (Pal et al., 2012a). These soils, therefore, contain less amount of fine clay smectite (15$20 \%$ ) as compared to $25-36 \%$ fine clay smectite in vertic intergrades and Vertisols (Pal et al., 2010). They are formed in the alluvium brought down from the Himalayan hinterland that contains $<2 \%$ plagioclase (Srivastava and Parkash, 2002; Srivastava et al., 2010; Pal et al., 2012a). Smectite in these soils is the alteration product of plagioclase during earlier humid climate in the source area as the formation of smectite from mica is improbable in humid climate (Pal et al., 2012a,b).

\section{Anthropogenic activities and soils of the IGP}

\subsection{Origin and dispersal of agriculture and its impact on soils of IGP}

The archaeological lines of evidence indicate the agriculture originated and dispersed from southwest Asia into South Asia (Fuller,
2006; Chen et al., 2010). The earliest phase of cultivation, wheat and barly, traces back to 11,000 BC-9000 BC from Euphrates River Valley, Syria, southwest Asia (Garrard, 2000; Hillman et al., 2001; Willcox, 2005; Fuller, 2006). The cereals recovered from Mehrgarh site (7000 $\mathrm{BC})$, south Asia mark the introduction of cultivation from the West (Costantini, 1983). Further east beyond the Indus valley, the earliest record of cultivation from northern Gujrat has been placed at $3500 \mathrm{BC}$ (Patel, 1999; Meadow and Patel, 2003). In the Gangetic Plains, the earliest agriculture dates back to early Harrapan period (2800 BC) with both summer and winter crops (e.g. site Kunaal; Fuller, 2006). It is, therefore, evident that the monsoonal crops were already available for cultivation over western parts of the IGP during the Harrapan period. This practice subsequently spread further east into the Gangetic Plains. The period after $2000 \mathrm{BC}$ is marked by agricultural village settlement over a wider region, covering landscapes with agriculturists and sedentary settlements (Fuller, 2006).

It is crucial to understand the impact of climatic transition to aridification during 4th and 3rd millennium BC on cultivation over the IGP. Prior to the transition, rainfall in the Indus Valley was probably more than double the amount received now. Such a high rainfall facilitated the flourishing both agriculture and forestry (Randhawa, 1945). The aridification set in during 4 th and 3rd millennium BC possibly caused the end of the great Harrapan civilization. The adverse climatic conditions induced precipitation of $\mathrm{CaCO}_{3}$, thereby depriving the soils of $\mathrm{Ca}^{2+}$ ions on the soil exchange complex with a concomitant development of sodicity in the subsoils. The subsoil sodicity impairs the hydraulic conductivity of soils. Therefore, the impairment of percolative moisture regime provides an example of a soil where gains exceed losses. This self-terminating process (Yaalon, 1983) leads to the formation of sodic soils with exchangeable sodium percentage (ESP) decreasing with depth. It has been opined that formation of pedogenic carbonate (PC) initiates the 
development of sodicity in such soils as a basic and natural process of soil degradation (Pal et al., 2000a). The semi-arid climatic episodes during Holocene favoured the formation PC in subsoils of the IGP. The rate of formation of PC is faster and of the order of $0.86 \mathrm{mg} / 100 \mathrm{~g}$ of soil/y in the first $100 \mathrm{~cm}$ of the profile at present (Pal et al., 2000a).

The canal irrigation introduced during the end of the 19th century in the north-western part of the IGP, is the other important factor that affects the IGP soils. It was introduced to minimize the problem of aridity and to stabilize crop yields. Although it resulted in the expansion of the cultivable area in the IGP, the practice of irrigation during the dry climate without the provision of drainage led to soil salinization and alkalinisation within a few years, due to rise in the groundwater table containing high proportion of sodium relative to divalent cations and/or high residual alkalinity (Abrol, 1982). In addition, the application of groundwater with high sodicity for irrigation also increased sodic soils in the IGP (Abrol, 1982).

\subsection{Natural and anthropogenic degradations and management interven-} tion in IGP soils

The IGP covers approximately $1 / 3$ cultivable area of India and produces nearly $50 \%$ of the country`s food grains for its population. Most of the land in the IGP has been cultivated using traditional mixed cropping methods until the middle of the 19th century. During the last 3-4 decades the agriculturists of the IGP have successfully increased food grain production by introducing high-input technologies to meet the demands of the exponentially growing population. The strategies and measures adopted to achieve this success included, among others, (i) the spread of high-yielding varieties, (ii) expansion of irrigated area, (iii) increased use of fertilizers, (iv) plant protection chemicals, ( $\mathrm{v}$ ) strengthening of marketing infrastructure, and (vi) introduction of subsidies (Abrol et al., 2002).

The IGP soils of HA, SAD, SAM, SHD climates are deficient in organic carbon due to high rate of decomposition. The adverse climatic conditions have caused the precipitation of $\mathrm{CaCO}_{3}$ with a concomitant development of sodicity in the subsoils (e.g. Hirapur, Ghabdan, Sakit and Zarifa Viran soils, units 16 and 23; Table 3). The management interventions of the National Agricultural Research Systems (NARS) have resulted in depletion of soil organic carbon in erstwhile Mollisols (e.g. Haldi soils, unit 26, Table 3). In addition, the rate of dissolution of PC during 30 months`cultural practice with gypsum in Zarifa Viran soils (Natrustalfs) has been estimated to be $254 \mathrm{mg} / 100 \mathrm{~g}$ soil in the top $1 \mathrm{~m}$ of the profile. This indicates a much higher rate of dissolution than its rate of formation $(0.86 \mathrm{mg} / 100 \mathrm{~g}$ soil/year) in the top $1 \mathrm{~m}$ profile (Pal et al., 2000a, 2009c). This is important as soil inorganic carbon (SIC) is more than double of the soil organic carbon (SOC) stock in the first $150 \mathrm{~cm}$ depth, which remains hidden and helps improve the drainage, establishment of vegetation, and sequestration of OC in soils (Bhattacharyya et al., 2004). The continuing agronomic practices by the NARS can provide the most important $\mathrm{Ca}^{2+}$ ions in both solution and exchange sites of soil. Such chemical environment would not allow Haplustalfs to transform to any other soil order so long $\mathrm{CaCO}_{3}$ continues to serve as a soil modifier (Pal et al., 2012c).

In addition to the impairment of drainage by sodicity some of the non-sodic soils are also marked by low hydraulic conductivity ( $\mathrm{HHC}$ $<10 \mathrm{~mm} / \mathrm{h}$ ) (Pal, 2012). Impairment of hydraulic conductivity in such soils is attributed to an increase in bulk density (BD) in the subsoils (Pal, 2012). The increase in BD in subsoils is due to compaction caused by modern agricultural implements used to meet the high demand of rice, wheat and potato crops. This situation however, may help in maintain yield of rice in rainy season and also in sequestering more soil organic carbon under sub-merged condition (Sahrawat, 2004; Sahrawat et al., 2005). However, the yield of the subsequent crop, such as wheat, is either plateauing or declining (Dhillon et al., 2010). A comparison of the 1980 and 2005 soil data reveals an overall increase in SOC stock in these soils under agricultural land use despite the increase in soil inorganic carbon (SIC) (Bhattacharyya et al., 2007; Pal et al., 2009b). The soil degradation in terms of development of sodicity, increase in SIC and BD, despite the positive balance of OC sequestration, is a matter of concern. In view of the vast area of the IGP, new research initiatives are needed for development of the historical soil-climate-crop databank. Such a databank will not only help in fine-tuning the existing NARS management interventions, but also make the future projections on the sustainability of the cropping system in the IGP (Dhillon et al., 2010).

\section{Conclusions}

This review provides state-of-art information on recent developments in the IGP soils. It uses additional new data from 60 pedons spread along the west hot arid climate to per-humid climate in the east, for understanding the pedogenic response to neotectonics, climatic fluctuations, and anthropogenic activities. The synthesis provides the following salient features of the IGP soils.

(i) Based on degree of development, five geomorphic surfaces, QIG1 to QIG5 with soil ages $0.5 \mathrm{ka}, 0.5-2.5 \mathrm{ka}, 2.5-5.0 \mathrm{ka}, 5.0-10 \mathrm{ka},>10 \mathrm{ka}$ respectively, are mappable in the IGP. These soil-geomorphic surfaces also correspond to the post-incisive chronosequences that evolved in response to interplay of fluvial processes, climatic fluctuations, and neotectonics during the Holocene.

(ii) The polygenetic attributes, illuvial clay pedofeatures, pedogenic carbonates, clay mineralogy, and stable isotope geochemistry, suggest the evolution of the IGP soils witnessed two humid phases (13.5-11.0 ka and 6.5-4.0 ka) with intervening dry climatic conditions.

(iii) Activation of the major faults, uplifting, sagging, and tilting of tectonic blocks due to the movement of the Indian Plate resulted in convexity of the major rivers towards west, widening-narrowing of the floodplains, increased sinuosity and shifting of streams. The pedogenic response to the neotectonics suggests upliftment of blocks caused break in the sedimentation and initiation of pedogenic activity under prevailing climate. Episodic uplift of different blocks resulted in a sequence of soils with varying degree of development.

(iv) Soils of the IGP across the topographic gradient $(<0.02 \%)$ with varying climate from hot-arid to per humid belong to Entisols, Inceptisols, Alfisols, and Vertisols orders. Some of the sodic soils (Natrustalfs) changed to Haplustalfs, and the Mollisols changed to Typic Haplustalfs after two decades of reclamation and agriculture. The major pedogenic processes in soils of the IGP during the Holocene are the addition and depletion of $\mathrm{OC}$, formation pedogenic $\mathrm{CaCO}_{3}$, illuviation of clay particles and argilli-pedoturbation.

(v) The IGP soils are, in general, micaceous, but some of the soils with the vertic characters are smectitic. The soils with micaceous and smectitic mineralogy were formed in alluviums derived from the Himalayas and Cratonic rocks respectively.

(vi) The archaeological lines of evidence indicate that the crops were originated and dispersed from southwest Asia into the Gangetic Plains in the east. The beginning of agricultural activity over the southwest Asia is represented by the site of Mehrgarh at $7000 \mathrm{BC}$ with further dispersal eastward over the upper and middle Gangetic Plains occurred around 2000 BC. Deforestation and cultivation of the IGP for over several millenniums has influenced the pedogenesis of the IGP.

(vii) The natural and anthropogenic degradation of the IGP soils are the potential threats that cause enhancement of the SIC and soil BD. These challenges require appropriate management interventions for restoring and maintaining soil health for sustainable agricultural production.

(viii) It is hoped that this review would be potentially useful as guideline 
for management of the IGP soils based on a better understanding of their pedology and their linkage to climate change, landscape stability, and anthropogenic activity. There is an urgent need to create historical soil-climate-crop data source that can be used in finetuning of management interventions. It will help system modellers to make future projections on sustainability of productivity in the IGP.

\section{Acknowledgements}

PS would like to acknowledge DST support (SR/S4/ES-21/Ganga Plain/ P2, SR/S4/ES-8/2003, DU/DST-PURSE grant 2009) for paleopedogenic/ pedogenic investigation of the Himalayan foreland. We thank Manoj, Spandana, Priscella, Shubendu, Naushad, and Ajay for their contribution in acquiring the new data in the field and in the laboratory. The authors would like to acknowledge previous workers: S.K. Singhai, S. Kumar, R. Mohindra, L. P. Singh and several researchers from NBSSLUP, Nagpur, for their contribution in IGP soils. This manuscript benefitted from the thoughtful reviews by Steven G. Driese and an anonymous reviewer.

\section{References}

Abrol, I.P., 1982. Reclamation and management of salt-affected soils. Review of Soil Research in India, Part II, 12th International Congress Soil Science, ISSS, IARI, New Delhi, pp. 635-654.

Abrol, Y.P., Sangwan, S., Dadhwal, V.K., Tiwari, M., 2002. Land use/land cover in IndoGangetic Plains - history of changes, present concerns and future approaches. In: Abrol, Y.P., Sangwan, S., Tiwari, M. (Eds.), Land Use-historical perspectives - focus on indo-gangetic plains. Allied Publishers Pvt. Ltd., New Delhi, pp. 1-28.

Aruche, K.M., 2014. Soil geomorphic variations of Gangetic Plains in response to the Late Quaternary Climatic Changes(Ph.D. thesis) University of Delhi, Delhi (258 pp.).

Bhatia, S.B., Singh, N., 1988. Middle Holocene paleoclimatic and paleoenvironmental events in southern Haryana. Bull. Indian Natl. Sci. Acad. 54, 574-584.

Bhattacharya, T., Banerjee, S.N., 1979. Quaternary geology and geomorphology of the Ajay-Bhagirathi Valley, Birbhum and Murshidabad districts. Indian J. Earth Sci. 6, 91-102.

Bhattacharyya, T., Pal, D.K., Chandran, P., Mandal, C., Ray, S.K., Gupta, R.K., Gajbhiye, K.S., 2004. Managing soil carbon stocks in the Indo-Gangetic Plains, India. Rice-wheat consortium for the Indo-Gangetic Plains, New Delhi, p. 44, (http://www.rwc-prism. cgiar.org and http://www.cimmyt.org).

Bhattacharyya, T., Chandran, P., Ray, S.K., Pal, D.K., Venugopalan, M.V., Mandal, C., Wani, S.P., 2007. Changes in levels of carbon in soils over years of two important food production zones of India. Curr. Sci. 93, 1854-1863.

Birkeland, P.W., 1974. Pedology, weathering and geomorphological research. Oxford, New York (285 pp.).

Birkeland, P.W., 1990. Soil development on stable landforms and implications for landscape studies. Geomorphology 3, 207-224.

Birkeland, P.W., 1999. Soils and geomorphology. Oxford, New York (448 pp.).

Bullock, P., Fedoroff, N., Jongerious, A., Stoops, G., Tursina, T., 1985. Handbook of soil thin section description. Waine Research Publication, (152 pp.).

Chen, S., Lin, B., Baig, M., Mitra, B., Lopes, R.J., Santos, A.M., Magee, D.A., Azevedo, M., Tarroso, P., Sasazaki, S., Ostrowski, S., Mahgoub, O., Chaudhuri, T.K., Zhang, Y., Costa, V., Royo, L.J., Goyache, F., Luikart, G., Boivin, N., Fuller, D.Q., Mannen, H., Bradley, D.G., Beja-Pereira, A., 2010. Zebu cattle are an exclusive legacy of the South Asia Neolithic. Mol. Biol. Evol. 27, 1-6.

Costantini, L., 1983. The beginning of agriculture in the Kachi Plain: The evidence of Mehrgarh. In: Allchin, B. (Ed.), South Asian Archaeology. Cambridge University Press, Cambridge, pp. 29-33.

Das, P., 1993. Thermoluminescence dating of soils of the western Gangetic Plains(M. Tech. Thesis) University of Roorkee, Roorkee (28 pp.).

Dhillon, B.S., Kataria, P., Dhillon, P.K., 2010. National food security vis-à-vis sustainability of agriculture in high crop productivity regions. Curr. Sci. 98, 33-36.

Eswaran, H., Sys, C., 1979. Argillic horizon in LAC soils formation and significance to classification. Pédologie 29, 175-190.

Fuller, D.Q., 2006. Agricultural origins and frontiers in South Asia: A working synthesis. J. World Prehistory 20, 1-86.

Fuloria, R.C., 1969. Geological framework of Ganga Basin. In: Bhattacharyya, S.N., Sastri, V.V. (Eds.), Selected lectures on Petroleum Exploration. Institute of Petroleum Exploration, Dehradun, pp. 170-186.

Gaina, C., Muller, R.D., Brown, B., Ishihara, T., 2007. Breakup and early seafloor spreading between India and Antarctica. Geophys. J. Int. 170, 151-169.

Garlapuri, V.N., 1984. Geomorphology of Haryana state. Proceedings 5th Asian Conference on Remote Sensing, Kathmandu, pp. 8.1-8.9.

Garrard, A., 2000. Charting the emergence of cereal and pulse domestication in SouthWest Asia. Environ. Archaeol. 4, 67-86.

Gaur, V.K., 1994. Evaluation of seismic hazard in India towards minimizing earthquake risk. Curr. Sci. 67, 324-329.
Gibling, M.R., Sinha, R., Roy, N.G., Tandon, S.K., Jain, M., 2008. Quaternary fluvial and eolian deposits on the Belan River, India: paleoclimatic setting of Paleolithic to Neolithic archaeological sites over the past 85,000 years. Quat. Sci. Rev. 27 (3-4), 392-411.

Gupta, H.P., 1978. Holocene Palynology from meander lake in the Ganga Valley, district Partapgarh, Uttar Pradesh. Palaeobotonist 25, 109-119.

Harden, J., 1990. Soil development on stale landforms and implications for landscape studies. Geomorphology 3, 391-397.

Hillman, G.C., Hedges, R., Moore, A.M.T., Colledge, S., Pettitt, P., 2001. New evidence of Late Glacial cereal cultivation at Abu Hureyra on the Euphrates. The Holocene 11, 383-393.

Huggett, R.J., 1998. Soil chronosequences, soil development, and soil evolution: a critical review. Catena 32, 155-172.

IMD, 2009. Normal Annual rainfall map of India. http://www.imd.gov.in/.

Jenny, H., 1941. Factors of soil formation: A system of quantitative pedology. McGrawHill, New York (281 pp.).

Kent, D.V., Muttoni, G., 2008. Equatorial convergence of India and early Cenozoic climate trends. Proc. Natl. Acad. Sci. 105, 16065-16070.

Khan, M.S.H., Parkash, B., Kumar, S., 2005. Soil-landform development of a part of the fold belt along the eastern coast of Bangladesh. Geomorphology 71, 310-327.

Klootwijk, C.T., Gee, J.S., Peirce, J.W., Smith, G.M., McFadden, P.I., 1992. An early India-Asia contact: paleomagnetic constraints from ninety east ridge, ODP leg 121. Geology 20 395-398.

Kumar, S., Parkash, B., Manchanda, M.L., Singhvi, A.K., Srivastava, P., 1996. Holocene landform and soil evolution of the western Gangetic Plains: implications of neotectonics and climate. Z. Geomorphol. (Suppl. 103), 283-312.

Kumar, P., Yuan, X., Kumar, M.R., Kind, R., Li, X., Chadha, R.K., 2007. The rapid drift of the Indian Tectonic Plate. Nature 449, 894-897.

Leather, J.W., 1898. On the composition of Indian soils. Agric. Ledger 4, 81-164.

Levine, E.L., Ciolkosz, E.J., 1983. Soil development in tillites of various ages in northern Pennsylvania. Quat. Res. 19, 85-99.

Mathur, V.K., 1969. Aithasic Sthanavali, Scientific and Technical Terminology Commission. Education Ministry, New Delhi (1040 pp.).

McFadden, L.D., Knuepfer, P.L.K., 1990. Soil geomorphology: the linkage of pedology and surficial processes. Geomorphology 3, 197-205.

McNeill, J.R., Winiwarter, V., 2004. Breaking the SOD: humankind, history and soil. Science 304, 1627-1629.

Meadow, R., Patel, A.K., 2003. Prehistoric pastoralism in North-western South Asia from the Neolithic through the Harappan period. In: Weber, S.A., Belcher, W.R. (Eds.), Indus ethnobiology. Lexington Books, Lanham, New perspectives from the field pp. 65-94.

Misra, V.N., 1984. Climate, a factor in rise and fall of the Indus Civilisation - evidence from Rajasthan and beyond. In: Lal, B.B.S., Gupta, S.P., Asthana, S. (Eds.), Frontiers of the Indus Civilisation.- Sir Mortimer Commem. Vol. Ind. Archael. Soc. And Ind. Hist. and Cult. Soc. (461-490 pp.).

Misra, V.N., 2001. Prehistoric human colonization of India. J. Biosci. 26, 491-531.

Mohindra, R., Parkash, B., Prasad, J., 1992. Historical geomorphology and pedology of the Gandak Megafan, Middle Gangetic Plains, India. Earth Surf. Process. Landf. 17, 643-662.

Morrisson, R.B., 1964. Lake Lahonton: Geology of southern Carson Desert, Nevada. U. S. Geolological Survey Professional Paper 401 (156 pp.).

Morrisson, R.B., 1965. Lake Bonneville: Quaternary stratigraphy of eastern Jordan Valley, south of Salt Lake city, Utah. U.S. Geolological Survey Professional Paper 477 (80 pp.)

Murthy, R.S., Hirekerur, L.R., Deshpande, S.B., Venkat Rao, B.V. (Eds.), 1982. Benchmark Soils of India. National Bureau of Soil Survey and Land Use Planning, Nagpur, India (374 pp.).

National Bureau of Soil Survey and Land Use Planning (NBSSLUP), 2002. Soils of India. 8185460-72-8, (NBSS Publication 94).

National Bureau of Soil Survey and Land Use Planning (NBSSLUP), 1992. Soils of West Bengal. 81-85460-12-4, (NBSS Publication 27b).

National Bureau of Soil Survey and Land Use Planning (NBSSLUP), 1995a. Soils of Punjab. 81-85460-26-4, (NBSS Publication 45b).

National Bureau of Soil Survey and Land Use Planning (NBSSLUP), 1995b. Soils of Haryana. 81-85460-24-8, (NBSS Publication 44b).

Pal, D.K., 2012. Pedogenic thresholds in benchmark soils under rice-wheat cropping system in a climosequence of the Indo-Gangetic alluvial plains. Indian Society of Soil Survey and Land Use Planning, NagpurSpecial Publication. Isslup, pp. 35-52.

Pal, Y., Sahai, B., Sood, R.K., Agarwal, D.P., 1980. Remote sensing of the lost Saraswati River Proc. Indian Acad. Sci. Earth Planet. Sci. 89, 317-331.

Pal, D.K., Kalbande, A.R., Deshpande, S.B., Sehgal, J.L., 1994. Evidence of clay illuviation in sodic soils of north-western part of the Indo-Gangetic Plains since the Holocene. Soi Sci. 158, 465-473.

Pal, D.K., Bhattacharyya, T., Deshpande, S.B., Sarma, V.A.K., Velayutham, M., 2000a. Significance of minerals in soil environment of India, NBSS Review Series 1. NBSS \& LUP, Nagpur.

Pal, D.K., Dasog, G.S., Vadivelu, S., Ahuja, R.L., Bhattacharyya, T., 2000b. Secondary calcium carbonate in soils of arid and smei-arid regions of India. In: Lal, R., Kimble, J.M. Eswaran, H., Stewart, B.A. (Eds.), Global climate change and pedogenic carbonates. Lewis Publishers, Boca Raton, Fl, pp. 149-185.

Pal, D.K., Srivastava, P., Durge, S.L., Bhattacharyya, T. 2003a. Role of microtopography in the formation of sodic soils in the semi-arid part of the Indo-Gangetic Plains, India. Catena 51, 3-31

Pal, D.K., Srivastava, P., Bhattacharyya, T., 2003b. Clay illuviation in calcareous soils of the semi-arid part of the Indo-Gangetic Plains, India. Geoderma 115, 177-192.

Pal, D.K., Bhattacharyya, T., Chandran, P., Ray, S.K., 2009a. Tectonics-climate-linked natural soil degradation and its impact in rainfed agriculture: Indian experience. In: Wani, S.P., Rockstroem, J., Oweis, T. (Eds.), Rainfed agriculture unlocking the potential. CABI International, Oxfordshire, U.K., pp. 54-72. 
Pal, D.K., Bhattacharyya, T., Chandran, P., Ray, S.K., Satyavathi, P.L.A., Durge, S.L., Raja, P. Maurya, U.K., 2009b. Vertisols (cracking clay soils) in a climosequence of Peninsular India: Evidence for Holocene climate changes. Quat. Int. 209, 6-21.

Pal, D.K., Bhattacharyya, T., Srivastava, P., Chandran, P., Ray, S.K., 2009c. Soils of the IndoGangetic Plains: their historical perspective and management. Curr. Sci. 96, 1193-1201.

Pal, D.K., Lal, Sohan, Bhattacharyya, T., Chandran, P., Ray, S.K., Satyavathi, P.L.A., Raja, P., Maurya, U.K., Durge, S.L., Kamble, G.K., 2010. Pedogenic thresholds in Benchmark soils under rice-wheat cropping system in a climosequence of the Indo-Gangetic Alluvial Plains. Final Project Report, Division of Soil Resource Studies. NBSS \& LUP, Nagpur (193 pp.).

Pal, D.K., Bhattacharyya, T., Sinha, R., Srivastava, P., Dasgupta, A.S., Chandran, P., Ray, S.K., Nimje, A., 2012a. Clay minerals record from Late Quaternary drill cores of the Ganga Plains and their implications for provenance and climate change in the Himalayan Foreland. Palaeogeogr. Palaeoclimatol. Palaeoecol. 356-357, 27-37.

Pal, D.K., Wani, S.P., Sahrawat, K.L., 2012b. Vertisols of tropical Indian environments: Pedology and edaphology. Geoderma 189-190, 28-49.

Pal, D.K., Bhattacharyya, T., Wani, S.P., 2012c. Formation and management of cracking clay soils (Vertisols) to enhance crop productivity: Indian experience. In: Stewart, B.A., Lal, R. (Eds.), World soil resources. Francis and Taylor, pp. 317-343.

Parkash, B., Kumar, S., 1991. Indo-Gangetic Basin. In: Tandon, S.K., Pant, C.C., Kashyap, S.M. (Eds.), Sedimentary Basins of India, Tectonic Context, Gyanodaya Prakashan, Nainita (147-170 pp.)

Parkash, B., Kumar, S., Rao, M.S., Giri, S.C., Kumar, C.S., Gupta, S., Srivastava, P., 2000. Holocene tectonic movements and stress field in the Western Gangetic Plains. Curr. Sci. 79, 438-449.

Patel, A.K., 1999. New radiocarbon determinations from Loteshwar and their implications for understanding settlement and subsistence in North Gujarat and adjoining areas. Paper presented in the Fifteenth International Conference on South Asian Archaeology, Leiden University, July 5-9, p. 1999.

Pati, P., Parkash, B., Awasthi, A.K., Jakhmola, R.P., 2012. Spatial and temporal distribution of inland fans/terminal fans between the Ghaghara and Kosi rivers indicate eastward shift of neotectonic activities along the Himalayan front. A study from parts of the upper and middle Gangetic plains, India. Earth-Sci. Rev. 115, 201-216.

Raiverman, V., Kunte, S., Mukherjee, A., 1983. Basin geometry, Cenozoic sedimentation and hydrocarbon prospects in northwestern Himalaya and Indo-Gangetic Plains. Pet. Asia J. 6, 67-92.

Rajagopalan, G., 1992. Radiocarbon ages of carbonate materials from Gangetic alluvium. In: Singh, I.B. (Ed.), Gangetic Plains: Terra Incognita. Lucknow University, Lucknow, pp. $45-48$.

Randhawa, M.S., 1945. Progressive desiccations of northern India in historical times. J Bombay Nat. Hist. Soc. 45, 558-565.

Rao, M.B.R., 1973. The subsurface geology of Indo-Gangetic Plains. J. Geol. Soc. India 14, 217-242.

Ray, S.K., Bhattacharyya, T., Chandran, P., Sahoo, A.K., Sarkar, D., Durge, S.L., Raja, P., Maurya, U.K., Pal, D.K., 2006. On the formation of cracking clay soils (Vertisols) in West Bengal. Clay Res. 25, 141-152.

Raychaudhuri, S.P., 1975. Evolution of classification of soils of India. Indian Agric. 19, $163-173$.

Richmond, G.M., 1962. Quaternary Stratigraphy of the La Sal Mountains, Utah. U.S. Geological Survey Professional Paper 334 (135 pp.).

Ritter, D.F., 1986. Process geomorphology. Wm. C. Brown, Dubuque Iowa (603 pp.).

Ruhe, R.V., 1956. Geomorphic surfaces and the nature of soils. Soil Sci. 82, 441-455.

Ruhe, R.V., 1960. Elements of soil landscape. Seventh International Congress, Soil Science, Maidson. Reprint Transactions 4, pp. 165-169.

Ruhe, R.V., 1964. Landscape morphology and alluvial deposits in southern Mexico. Ann. Assoc. Am. Geogr. 54, 147-159.

Ruhe, R.V., 1969. Quaternary landscapes in Iowa. Iowa State University Press, Ames (255 pp.).

Sahrawat, K.L., 2004. Organic matter accumulation in submerged soils. Adv. Agron. 81, 169-201.

Sahrawat, K.L., Bhattacharyya, T., Wani, S.P., Chandran, P., Ray, S.K., Pal, D.K., Padmaja, K.V., 2005. Long-term lowland rice and arable cropping effects on carbon and nitrogen status of some semi-arid tropical soils. Curr. Sci. 89, 2159-2163.

Sastri, V.V., Venkatachala, B.S., Bhandari, L.L., Raju, A.T.R., Datta, A.K., 1971. Tectonic framework and subsurface stratigraphy of the Ganga Basin. J. Geol. Soc. India 12, 222-233.

Saxena, A., Prasad, V., Singh, I.B., Chauhan, M.S., Hasan, R., 2006. On the Holocene record of phytoliths of wild and cultivated rice from Ganga Plain: evidence for rice-based agriculture. Curr. Sci. 90, 1547-1552.

Sehgal, J.L., 1974. Classification and distribution of the soils of Punjab. Proc. Indian Natl. Sci. Acad. 40, 404-419.

Sen-Gupta, S., 1966. Geological and geophysical studies in western part of Bengal Basin, India. Am. Assoc. Pet. Geol. Bull. 50, 1001-1018.

Shankarnarayana, H.S., Sarma, V.A.K., 1982. Soils of India. In: Murthy, R.S., et al. (Eds.), Benchmarks soils of India - morphology, characteristics and classification for resource management. NBSS \& LUP, Nagpur, pp. 41-69.

Sharma, G.R., Misra, V.D., Mandal, D., Misra, B.B., Pal, J.N., 1980. Beginning of agriculture Avinash Prakashan, Allahabad, pp. 133-200.
Singh, G., 1971. The Indus Valley Culture. Archaeology and Physical Anthropology in Oceania 6, pp. 177-189.

Singh, I.B., 1988. Geological evolution of Gangetic Plains - What we know and what we do not know? Workshop on Gangetic Plains - Terra Incognita. Lucknow University, Lucknow (Abstract volume).

Singh, G., Joshi, R.D., Chopra, S.K., Singh, A.B., 1974. Late Quaternary history of vegetation and climate of the Rajasthan desert, India. Philos. Trans. Royal Soc. Lond. 267, 467-501.

Singh, H., Parkash, B., Gohain, K., 1993. Facies analysis of the Kosi megafan deposits. Sediment. Geol. 85, 87-113.

Singh, L.P., Parkash, B., Singhvi, A.K., 1998. Evolution of the lower Gangetic Plain landforms and soils in West Bengal, India. Catena 33, 75-104.

Singh, S., Parkash, B., Rao, M.S., Arora, M., Bhosle, B., 2006. Geomorphology, pedology and sedimentology of the Deoha/Ganga-Ghghara Interfluve, Upper Gangetic Plains (Himalayan Foreland Basin) - extensional tectonic implications. Catena 67, 183-203.

Singhai, S.K., Parkash, B., Manchanda, M., 1991. Geomorphological and Pedological evolution of Haryana state. Bulletin Oil and Natural Gas Commission 28, pp. 37-60.

Sinha, R., Friend, P.F., 1999. Pedogenic alteration in the overbank sediments, north Bihar Plains. J. Geol. Soc. India 53, 163-171.

Sinha, R., Friend, P., Switsur, V.R., 1996. Radiocarbon dating and sedimentation rates in the Holocene alluvial sediments of the northern Bihar Plains, India. Geol. Mag. 133, 85-90.

Srivastava, P., 2001. Paleoclimatic implications of pedogenic carbonate in Holocene soils of the Gangetic Plains. Palaeogeogr. Palaeoclimatol. Palaeoecol. 172, 207-259.

Srivastava, P., Parkash, B., 2002. Polygenetic soils of the north- central part of the Gangetic Plains: a micromorphological approach. Catena 46, 243-259.

Srivastava, P., Parkash, B., Sehgal, J.L., Kumar, S., 1994. Role of neotectonics and climate in development of the Holocene geomorphology and soils of the Gangetic Plains between Ramganga and Rapti rivers. Sediment. Geol. 94, 119-151.

Srivastava, P., Parkash, B., Pal, D.K., 1998. Clay minerals in soils as evidence of Holocene climatic change, central Indo-Gangetic Plains, north-central India. Quat. Res. 50, 230-239.

Srivastava, P., Rajak, M.K., Sinha, R., Pal, D.K., Bhattacharyya, T., 2010. A high resolution micromorphological record of the Late Quaternary Paleosols from Ganga-Yamuna Interfluve: Stratigraphic and Paleoclimatic implications. Quat. Int. 227, 127-142.

Tandon, S.K., Sinha, R., Gibling, M.R., Dasgupta, A.S., Ghazanfari, P., 2008. Late Quaternary evolution of the Ganga Plains: myths and misconceptions, recent developments and future directions. Golden Jubilee Memoir of the Geological Society of India 66, pp. 259-299.

Valdiya, K.S., 1976. Himalayan transverse faults and folds and their parallelism with subsurface structures of north Indian Plains. Tectonophysics 32, 353-386.

Velayutham, M., Pal, D.K., 2004. Soil classification, India. Encyclopedia of soil science. Marcel Dekker, New York (1-3 pp.).

Velayutham, M., Pal, D.K., Bhattacharyya, T., Srivastava, P., 2002. Soils of the Indo-Gangetic Plains, India - the historical perspective. In: Abrol, Y.P., Sangwan, S., Tiwari, M. (Eds.), Land Use - historical perspectives - focus on Indo-Gangetic Plains. Allied Publishers, New Delhi, pp. 61-70.

Voelcker, J.A., 1893. Improvement of Indian agriculture. Report submitted to Famine Commission of 1880. Imperial and Provincial Agricultural Department, India.

Vohra, M.S., 1987. Thermoluminescence dating of fluvial terraces: A feasibility study(M. Tech. Thesis) University of Roorkee, Roorkee.

Vreeken, W.J., 1975. Principal kind of soil chronosequences and their significance in soil history. J. Soil Sci. 26, 378-390.

Wadia, D.N., 1966. Geology of India, 6th ed. McMillan, London (531 pp.)

Wadia, D.N., Krishnan, M.S., Mukherjee, P.N., 1935. Introductory note on the geological formation of the soils of India. Rec. Geol. Surv. India 68, 369-391.

Wasson, R.J., 2006. Human interaction with soil-sediment systems in Australia. In: McNeil, J.R., Winiwarter, V. (Eds.), Towards a world environmental history of soils. Oregon State University Press, Cambridge, pp. 243-272.

Wells, N.A., Dorr Jr., J.A., 1987. Shifting of the Kosi River, northern India. Geology 15, 204-207.

Willcox, G., 2005. The distribution, natural habitats and availability of wild cereals in relation to their domestication in the Near East: multiple events, multiple centres. Veg. Hist. Archaeobot. 14, 534-541.

Williams, M.A.J., Clarke, M.F., 1984. Late Quaternary environments in North-Central India. Nature 308, 633-635

Williams, M.A.J., Clarke, M.F., 1995. Quaternary geology and prehistoric environments in the Son and Belan valleys, north central India. Mem. Geol. Soc. India 32, 282-308.

Williams, M.A.J., Pal, J.N., Jaiswal, M., Singhvi, A.K., 2006. River response to Quaternary climatic fluctuations: evidence from the Son and Belan valleys, north-central India. Quatern. Sci. Rev. 25, 2619-2631.

Yaalon, D.H., 1983. Climate, time and soil development. In: Wilding, L.P., Smeck, N.E., Hall, G.F. (Eds.), Pedogenesis and Taxonomy, I. Concepts and Interactions. Elsevier, Amsterdam. 